\title{
Temperature Measurement-Inquiry-Based Learning Activities for Third Graders
}

\author{
Žaneta Gerhátová, Peter Perichta, Marián Drienovský (i) and Marián Palcut *(i)
}

Citation: Gerhátová, Ž.; Perichta, P.; Drienovský, M.; Palcut, M.

Temperature Measurement-InquiryBased Learning Activities for Third Graders. Educ. Sci. 2021, 11, 506. https://doi.org/10.3390/ educsci11090506

Academic Editor:

Konstantinos Ravanis

Received: 21 July 2021

Accepted: 1 September 2021

Published: 5 September 2021

Publisher's Note: MDPI stays neutral with regard to jurisdictional claims in published maps and institutional affiliations.

Copyright: (c) 2021 by the authors. Licensee MDPI, Basel, Switzerland. This article is an open access article distributed under the terms and conditions of the Creative Commons Attribution (CC BY) license (https:// creativecommons.org/licenses/by/ $4.0 /)$.
Institute of Materials Science, Faculty of Materials Science and Technology in Trnava, Slovak University of Technology, 91724 Trnava, Slovakia; zaneta.gerhatova@stuba.sk (Ž.G.); peter.perichta@gmail.com (P.P.); marian.drienovsky@stuba.sk (M.D.)

* Correspondence: marian.palcut@stuba.sk

\begin{abstract}
The article presents our Inquiry-Based Learning (IBL) activities in the project-based Science education of third graders (8-9-year-old pupils) in the Slovak Republic. Individual tasks of project assignment titled "Temperature Measurement" were conceived for "guided inquiry". We also supported the IBL of pupils by interactive education strategy-Integrated e-Learning (INTe-L). The strategy was built on the role of interactive simulations and experimenting at the knowledge acquisition. The following INTe-L components were used: (a) on-site and remote experiments, (b) interactive simulations and (c) electronic study materials. The research was based the hypothesis that the project-based teaching of the topic "Temperature Measurement" using the IBL activities is significantly more efficient than traditional (instructivist) way of teaching. To verify the hypothesis, we carried out a pedagogical experiment on a sample of 60 respondents. The third graders were divided into two parallel groups: an experimental group (EG, 30 pupils) and control group (CG, 30 pupils). To get a relevant feedback, pre-test and post-test were developed and applied. The results attained in the EG were statistically processed, evaluated, and subsequently compared with those in the CG. The analysis of the results attained by the EG showed that their knowledge acquisition has been increased by $24 \%$ compared to CG. We have created a methodology for making simple scientific project assignments with the implementation of all components of the new integrated e-learning education strategy (real and real remote experiment, e-simulation, e-learning material). On a specific example of the topic "Temperature Measurement" in primary education, we have presented the possibility of using a "guided inquiry" in the implementation of individual experimental tasks. We have introduced a form of teamwork that allows to harmonize the teaching requirements with individual learning approach and helps to prepare pupils for planned work and independent knowledge acquisition and problem solving. The study has shown that complex IBL activities can be successfully applied at primary school 3rd grade level already. Our form of education with the wider use of modern information and communication technologies (ICT) was attractive for the learners and helped them to develop interdisciplinary relationships. The integrated e-learning has helped third grades to develop a deeper conceptual understanding of temperature and allowed them to prepare presentations to demonstrate their conceptual knowledge. The approach allowed pupils to gain key competencies in Science (discussion and presentation of results). It has also increased the pupils' interest in Science in general and helped them to understand links between different subjects.
\end{abstract}

Keywords: integrated e-learning; inquiry-based learning; primary school; 3rd-grade pupils; project; Science; temperature measurement

\section{Introduction}

People live in a society surrounded by a variety of information and communication technologies (ICT). Children operate their parents' television sets, mobile phones, iPads, and personal computers. They watch videos and play computer games since their early childhood. Their advanced knowledge of ICT is a natural consequence of a rapidly changing society. In this context, the following question arises: "How to integrate the ICT into 
teaching to actively engage pupils in the discovery of new knowledge?" The answer to the question is neither simple nor unambiguous. Teachers try to embrace the pupils' interest in ICT and facilitate its use at school. The effectiveness of the ICT usage, however, depends on the teaching methods, the teacher's personality, his/her pedagogical mastery, as well as on the nature and specifics of the subject. It also depends on the competence of the learner and their environment [1].

One option for how to improve the teaching of science is the use of Inquiry-based learning (IBL). IBL aspires to engage students in an authentic scientific discovery process [2]. The IBL is an educational strategy in which students follow methods and practices routed in professional science to construct knowledge [3]. It is an active, learner-centered approach focusing on questioning, critical thinking, and problem solving. The learner is actively involved in question formulation and its solution [4]. The use of ICT in IBL is not a goal, but a welcomed step forward in the process. The IBL represents a constructivist approach to science education [5]. It is viewed as an alternative means for the learning and understanding of scientific concepts. In IBL, the process of inquiry is the key element [6]. The IBL can positively affect the students' learning outcomes by enabling open inquiries [7]. It provides a unique opportunity to introduce thoughtful insights into already-known facts about the surrounding natural environment [8]. The IBL is meant to reflect the methods and processes of modern science as closely as possible. The essential component is the scientific experiment. The experiment helps pupils to grasp the very essence of real research and acquire new knowledge. The learning takes place in situations intentionally created by teachers, thereby enabling the pupils to observe real natural phenomena, manipulate specific objects, conduct experiments, engage in live discussions, and take an active part in practical problem solving [9].

IBL is often organized into inquiry phases that together form an inquiry cycle. However, different variations on what is called the inquiry cycle can be found in literature [2,10]. An example of the research activities hierarchy, adapted by the participants of the ESTABLISH project [11], is presented in Figure 1. It focuses on the following activities (from bottom to top): interactive demonstration, confirmation inquiry, structured inquiry, guided inquiry, and open inquiry. As young children have a limited cognitive processing capacity, they should be guided by their teacher. In "guided inquiry", the teacher establishes a problem to the learners and their role is to propose a concrete solution. The pupils' ability to use the previously acquired skills in solving new problems is tested during the problemsolving process. The problems are introduced through simple verbs, such as, "measure", "examine", "observe", "find out", or "define". The learners find these tasks easy to solve, and propose the problem-solving procedure themselves, only with a minimum guidance from the teacher [10]. The instructional strategies can be moved toward open inquiry. In the "open inquiry", the children are able to formulate their own questions and design their own investigations [12,13]. In open IBL, the teachers encourage their pupils to conduct a self-designed, interest-driven inquiry to find answers to their own research questions. It has been shown that minimal guidance during IBL does not work [14]. Therefore, the teachers' efforts during the process are directed towards facilitating, supervising, and supporting their pupils at the knowledge acquisition [15]. 


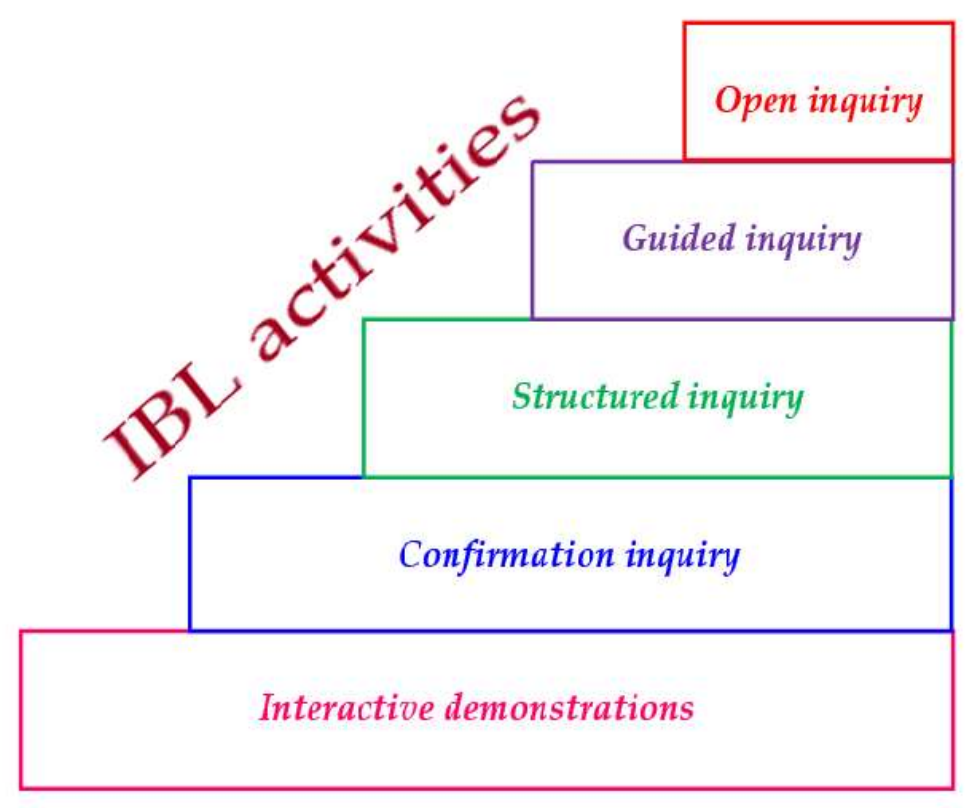

Figure 1. IBL activities.

Primary school pupils tend to be very curious and motivated to learn [13]. Cognitive and developmental psychology research studies have shown that environmental effects are important during early age development. The lack of stimuli at this time may lead to a child's underdevelopment [16]. Several researchers suggest that science education should begin in the early years of schooling [17-19]. To teach the scientific concepts efficiently, however, it is necessary to understand the nature of children's ideas about the world surrounding them. Young children tend to regard objects from a human-centered (selfcentered) point of view. As such, they often attribute human aspects, such as emotions, to different objects and phenomena $[20,21]$. The children's misconceptions and alternative conceptions of scientific expressions are deeply rooted in their daily life experiences. Several different factors may influence the children's misconceptions of natural phenomena. Duit and Treagust proposed six possible sources for alternative children's conceptions: cultural background, language experience, sensory experience, mass media, peer groups, and science instruction [22]. A poor science instruction in early childhood may result in negative student attitudes and underperformance, and these difficulties may pertain well into college years [23]. The early exposure to science, however, can help children foster their scientific reasoning skills, encourage positive attitudes toward scientific subjects, and provide a solid foundation for their later academic studies.

Heat and temperature are difficult concepts for primary school children to understand because of their abstractness. Heat is defined as an energy that is transferred from a place with higher temperature to a region of lower temperature [24]. Heat has its roots in the thermal motion of atoms and molecules. It is a thermodynamic quantity that is represented by symbols and mathematical equations. Tang and Tan show that heat is defined as "a network of semantic meanings, assembled across multiple representation modes" [25]. Previous studies have indicated that young children had difficulties in making semantic links between different concepts used by the scientific community [26,27]. Scientific terms such as heat and temperature are often misunderstood [28,29]. Sozbili reviewed scholarly literature on students' misconceptions on heat and temperature [30]. The author found that students' misconceptions vary with age. The following misconceptions of students 6-13 years old have been identified: 1 . There are two types of heat, cold heat and hot heat; 2. Heat is a material substance such as air or steam; and 3. The temperature of an object is related to its size. Thomaz, Malaquias, Valente, and Antunes observed that children had problems with identifying the nature of heat [31]. They believed that heat was a "substance" residing in physical objects. Their misconception originated from 
a fact that heat can be transported from one object to another. The concepts of heat and temperature are closely associated. The close association means that students have problems distinguishing between the two and use heat and temperature interchangeably in explaining thermal-related phenomena. Regarding the concept of temperature, Paik, Cho, and Go observed that students had difficulties linking it with a measurement of a physical quantity [26]. Some pupils thought of temperature as a material's property or physical instrument for heat measurement. The students also tended to summarize temperature the same way as heat [31].

It is now agreed that the learning of fundamental thermal concepts needs to address both semantic and semiotic challenges. Studies with pre-school and early school children related to concepts of heat and temperature focused on their understanding of water phase transformations [32-37]. Kambouri-Danos, Ravanis, Jameau, and Boilevin investigated a construction of a precursor model that can support children's scientific learning [33]. Their intervention had eight stages, during which children's predictions and explanations of water phase transformations were recorded. Russell et al. [35] and Bar [37] developed several activities related to water evaporation and used them to categorize children's mental representations. Previous studies also focused on demonstrating a thermal expansion of metals to children aged 5-6 [38], thermal conduction in metals [39], gasification [40], and combustion [41]. Furthermore, a recognition of a thermometer and its functioning was also explored [42]. The studies had a relatively short duration and a small number of activities due to the limited cognitive capacities of kindergarten children. An IBL approach in Preschool Science Education has been utilized by Cruz-Guzmán, García-Carmona, and Criado [43]. The science content taught to children aged 2-4 was related to the phase transformations of water and edible products (chocolate bar and ice pops). A positive evolution in children's conceptions and their ability to formulate predictions and to test them via experimentation have been noted [43]. Therefore, it has been suggested to implement IBL activities from the beginning of Preschool Education. Bar studied the views of children aged 5-15 on the water cycle [32]. The author found that children's conceptions of evaporation varied with age. It has been suggested that the teaching of the water cycle should be introduced around the age of 9, when some conception of evaporation has already been established. In a recent study, Yeo et al. used an image-to-writing approach to explain temperature and heat to primary school fourth graders (aged 9-10, [44]). The approach was guided by visualization techniques used by researchers. The authors exposed their pupils to images (photos, drawings, graphs) and asked them to describe their own thoughts about heat and temperature and translate them into textual representations using scientific terminology. The experimental group (EG) of primary school fourth graders received an inquiry-based instruction built on the image-to-writing approach [44]. In the control group, the pupils received a blend of direct instruction and inquiry activities without explicitly focusing on multimodal representations. It was revealed that a large fraction of pupils in the EG improved their levels of conceptual understanding after instruction. An image-towriting teaching approach may help primary school pupils to develop a deeper conceptual understanding. They can use images as representations of their conceptual understanding of heat and temperature concepts. The approach is closely related to inquiry-based learning.

Inquiry-based science learning proved to be stimulating for students' motivation, research skills acquisition, and construction of meaningful conclusions [45]. IBL has been shown to correct students' misconceptions about energy and thermodynamics [46]. Nevertheless, the implementation of IBL in primary school classrooms may not be a simple task [47-50]. Zion et al. [15] mentioned that teachers often experience difficulties in supporting their pupils through the process of inquiry. The formulation of research question and investigation design are both challenging [47]. Therefore, the primary school teachers need to be taught how to use a new technology and how to support their students in project-based learning (PBL). Yet, they must also feel confident that their pupils are fully capable of this kind of active learning [49]. 
The major objective of our study was to determine the effectiveness of project-based science teaching with the support of IBL activities at primary schools. The results of the pedagogical experiment were compared with traditional (instructivist) teaching. The following research question has been formulated: What is the effectiveness of the Project-based teaching of the topic of "Temperature Measurement" in the third grade Science lessons in the selected primary school in the Slovak Republic using the IBL activities and the INTe-L strategy? In this paper, we describe our IBL activities of the "Temperature measurement" topic for primary school third graders aged 8 to 9 . We believe the teachers will find the results of our study interesting and worthy of application in their pedagogical praxis.

\section{Materials and Methods}

\subsection{The Problem of Research}

In this paper, we aim to demonstrate a concrete example of IBL activities in the project titled "Temperature Measurement" in Science lessons for primary school third graders. We have designed the project for structured inquiry and supported the pupils' research activities with the latest ICT, as declared by the Integrated e-Learning (INTe-L) education strategy [51]. The main idea of the INTe-L strategy is based on the belief that when acquiring knowledge and skills in science, the pupils should follow the steps of scientific discovery [52]. They begin by observing the examined phenomenon, continue with their inquiry, and experiment with the aid of their teacher. Real on-site, real remote experiments, and virtual experiments (interactive simulations) can be implemented. Subsequently, the pupils process the acquired data and evaluate the results. The procedure ultimately leads to a confrontation of the theory acquired by pupils via textbooks and e-learning materials. The pupils thus evaluate the results, internalize concepts related to the issues they have examined, and finally find their way to a meaningful and deep understanding of physical phenomena and laws [53].

\subsection{Methodology of Research}

Our pedagogical research was conducted over a period of two consecutive years. In the first year, we carried out pre-research on a small sample-15 pupils of 3rd grade of primary school. The pre-research focused on verifying the possibility of using the IBL activities and INTe-L strategy in project-based teaching, detection of potential drawbacks, and determining whether the research instruments (pretest, posttest) would work. In our preliminary research, we studied whether the project work had the expected duration (1 week), the pupils understood the instructions and tasks, and whether they were able to finish the project assignment. The results of pre-research were not statistically evaluated due to the limited number of pupils.

The main research was conducted in the second year. During our pedagogical experiment, we used several methods. At the beginning, we started with a literature review. We used the literature review method [54] to review professional literature on IBL and to determine the state of the art in Slovakia and abroad. Later, we proceeded with the experiment. In our pedagogical experiment, we used the technique of parallel groups [55]. In this technique, we worked with two student groups: experimental and control. The group in which the IBL was used as the main teaching strategy was designated as experimental group. A group in which the IBL was not performed was designated as control group. Analysis and synthesis methods [56,57] were used in processing of research results. Finally, statistical methods [58] were used for statistical processing of obtained data and for evaluation of results.

To quantify the efficiency of IBL activities, we used a didactic testing. Two tests were designed: pre-test and post-test. Based on the evaluation of the pre-test results, we determined the level of students' entry knowledge that could affect the results of post-tests later (if they were very different in individual groups). Using a post-test, we determined and compared the level of output knowledge of learners in the control and experimental groups on the topic of "Temperature measurement". When creating non-standardized 
didactic tests (DT), we followed a general algorithm given in [59]. Namely, we determined the goal and framework content of each DT. Furthermore, we determined the test time and the number of tasks for each DT. We assigned weight to the tasks and determined the scoring for each DT. We preliminarily verified each DT. Finally, we had each DT assessed by a methodologist. Based on his recommendations, we performed the final adjustment of individual DTs.

We assumed that there was a relationship between the pupils' level of knowledge and the use of teaching methods, organization forms, and teaching resources used in the pupils' learning process. The following hypothesis was postulated:

Hypothesis 1 (H1). Project-based teaching of the topic "Temperature Measurement" in the 3rd grade Science lessons in the selected primary school in the Slovak Republic using the IBL activities and the INTe-L strategy is more efficient than traditional way of teaching.

\subsection{Sample of Research}

In one school year, we conducted a pedagogical experiment in science lessons of the 3rd grades (8-9 years old) in one Slovak primary school. The school was located in West Slovakia. The main objective was to determine the suitability of the project-based teaching using the IBL activities for the topic "Temperature Measurement". The sample was selected based on convenience sampling and consisted of one experimental group (EG, 30 pupils) and one control group $(\mathrm{CG}, 30)$ pupils. Pupils of the CG were taught by the traditional (instructivist) methods while pupils of EG were taught by the project-based Science teaching with the support of IBL activities and INTe-L strategy.

\subsection{Instrument and Procedures}

According to the State Education Program of the Slovak Republic (ISCED 1, 2011 [60]), the topic "Temperature Measurement" is included in the teaching topic "Heat and temperature". According to ISCED 1 [60], in this topic the pupils find out the answers to the following questions: "How can we measure the temperature?", "How does a thermometer work?", and "Which objects are hot and cold?". According to ISCED [60], the pupils should know at the end of teaching that they can first use a hand contact to estimate the objects temperature. Furthermore, they should know that the temperature is more precisely measured with a thermometer. They should be able to measure their body temperature with medical thermometer. Furthermore, pupils should be able to distinguish several different types of thermometers. Finally, they should be able to construct a simple thermometer using a glass bottle, water, straw, and plasticine and use it to measure water temperature.

We measured the entry-level of pupils' knowledge by a didactic pre-test since their prior acquaintance with the topic could influence their final results. Teaching in both groups took place in the same grade (3rd grade), in the same subject (Science), and the same topic was taught ("Temperature Measurement"). Furthermore, the teachers were equally qualified and had more than 10 years of school praxis.

Prior to the actual project execution, the pupils were acquainted with the project topic and its objectives and with the method of results assessment. The pupils in the EG worked in several small groups. After the project completion, there was a presentation of the results of the individual groups, followed by discussion and evaluation based on criteria given beforehand. As part of guided inquiry, we gave students a greater opportunity for freedom. Each group was free to choose the form of project presentation, either lecture or poster. The most frequently used form of pupils' presentation was the poster. The IBL activities are important for the pupil's development of higher order thinking skills. The learners' ability to analyze, synthesize, and evaluate information may be enhanced by visual representation, such as imaging [44] or modelling [61]. It is therefore advised to engage students in active demonstration of their knowledge using different media. Teachers should be encouraging the divergent thinking of their students and give them freedom to formulate their own 
questions. By active presentation of results, the students can acquire effective strategies for discovering and demonstrating the answers $[62,63]$. The higher order thinking skills gained during IBL activities in Science are also transferable to other subjects.

2.4.1. Inquiry-Based Learning Activities of the Project Titled "Temperature Measurement" (Project Assignment for EG)

\section{Task 1. Body temperature}

Answer the following questions (Figure 2):

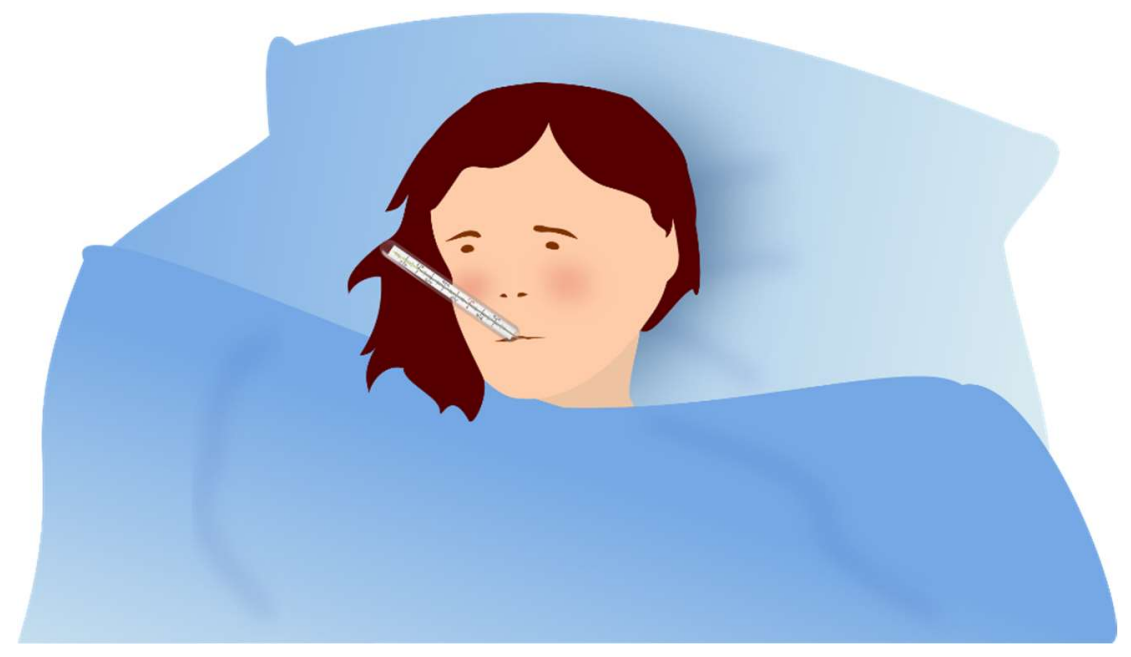

Figure 2. Feverish woman [64].

Look at Figure 2. What do you see? When was the last time you were ill? Did you have a fever? Who measured your body temperature? Which instrument was used to measure your temperature? What kind of thermometer was it? Can you measure your own body temperature? Do you know other kinds of thermometers? What can we measure with them?

Goal: To describe a real situation.

Task 2. Objects with different temperatures

Organize the objects in pictures (Figure 3) from the coldest to the warmest.

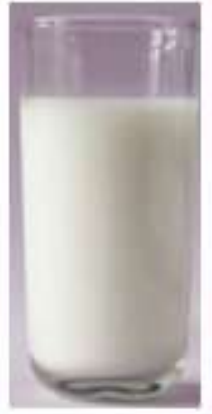

(a)

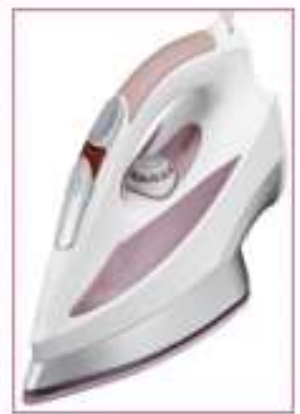

(b)

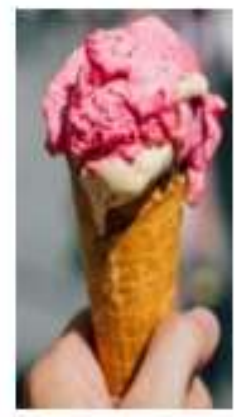

(c)

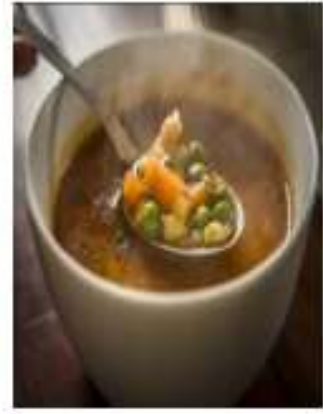

(d)

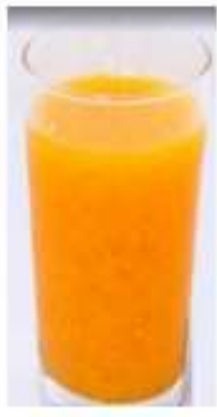

(e)

Figure 3. Pictures of objects with different temperatures (a) Hot milk [65]; (b) Iron switched on to the maximum [66]; (c) Ice cream [67]; (d) Hot soup [68]; (e) Orange juice [69].

Tools: Pictures of objects of different temperatures.

Procedure: Based on your own experience organize the objects on the pictures (Figure 3a-e) from the coldest to the warmest. 
Goal: Based on personal experience, pupils are able to estimate temperatures of different objects.

\section{Task 3. Home-made thermometer}

Conduct the following experiment.

Tools: a test tube, a narrow glass tube, water, ink, food coloring, a cork with an opening for the tube, an electric kettle, two glass containers (e.g., beakers).

Procedure: Pour some cold water into the test tube and color it with a few drops of either ink or food coloring. What is the ink/food coloring in the water for? Insert the glass tube into the cork opening and then seal the test tube with the cork (Figure 4). Your teacher will heat up the water in an electric kettle for you. The teacher will pour the hot water into a glass container. Place the test tube with the ink (Figure 4) or food coloring into the glass container. Make assumptions about what is going to happen. Observe what is really happening. Describe and explain the changes that occurred during the experiment. Remove the test tube out of the glass container filled with hot water and immense it in another container filled with cold water. Make assumptions about what is going to happen. Observe what is really happening. Describe the changes and explain them. Have your assumptions been in agreement with what you really observed during the experiment? Based on the results of the experiment, explain the principle of thermometers.

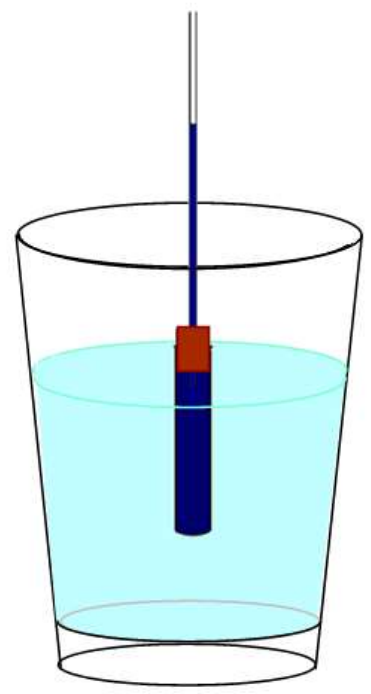

Figure 4. Home-made thermometer.

Goal: To explain the volume expansion of liquids depending on their temperature.

Task 4. Heating of ice-cold water

Conduct the following experiment.

Tools: a laboratory thermometer, drinking water $(1 \mathrm{~L}), 2$ glasses, ice cubes, electrical kettle, glass stick.

Procedure: Estimate the temperature of the water with some pieces of ice in it (Figure 5). Insert the laboratory thermometer into the iced water. Measure the temperature. Record the measured temperature in a table that has been prepared beforehand. Was your estimation correct? 


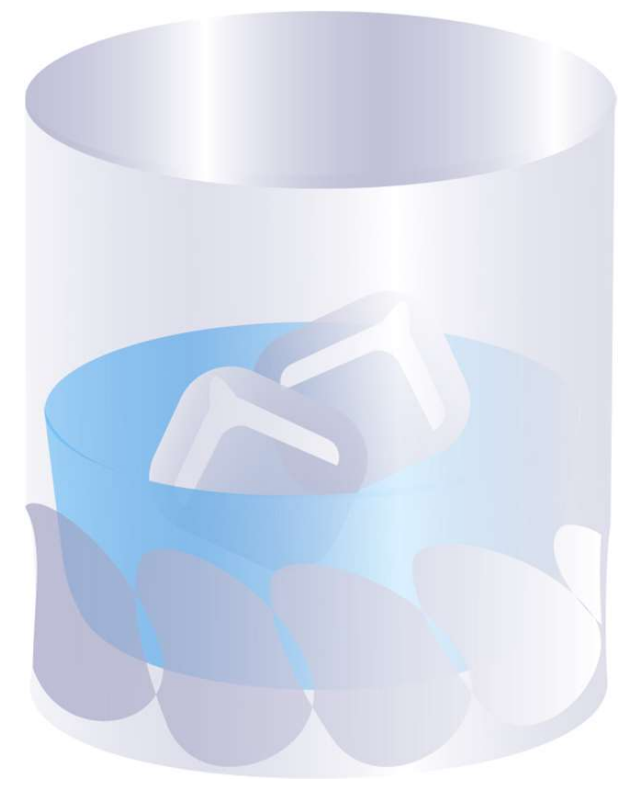

Figure 5. Iced water in a glass [70].

The teacher will boil some water in an electrical kettle and pour it into the glass. Insert the laboratory thermometer into the glass of hot water and measure the temperature. Record it in the table. Slowly pour some hot water into the ice-cold water, stir it with a glass stick and measure the resulting temperature. Write down the measured water temperature. Describe what you just observed and formulate a conclusion.

Goal: To observe the change of water temperature in a glass container filled with ice by pouring warm water into the glass.

Task 5. Experiment with interactive simulation titled "Energy Forms and Transformations".

Tools: personal computer or iPad, Internet access.

Procedure: Click on [71] and open the interactive simulation titled "Energy Forms and Transformations" (Figure 6). Observe the temperature increase of individual objects on the interactive simulation. Find out the various ways to increase the temperature of objects in the interactive simulation.

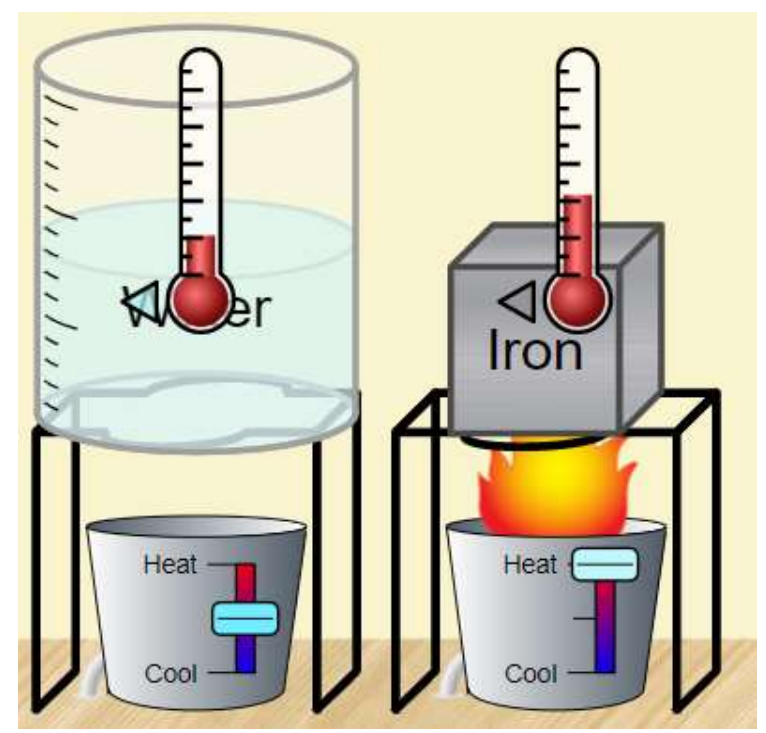

Figure 6. Interactive simulation of boiling process [71]. 
Observe the temperature decrease of individual objects on the interactive simulation. Find out the various ways to decrease the temperature of objects in the interactive simulation.

Goal: To demonstrate the increase and decrease of temperature by heating up or cooling down objects in an interactive simulation.

Task 6. Different thermometers.

Tools: The cards with names of different types of thermometers (Figure 7), pictures showing different types of thermometers (Figure $8 \mathrm{a}-\mathrm{d}$ ).

\section{Bimetallic thermometer}

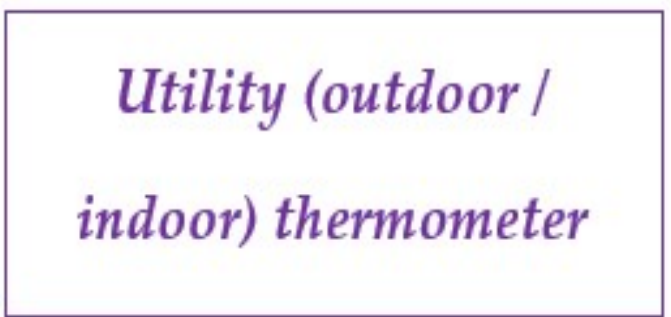

\section{Medical thermometer}

\section{Laboratory}

\section{thermometer}

Figure 7. The cards with names of different types of thermometers.

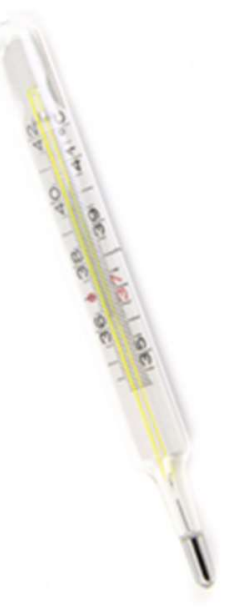

(a)

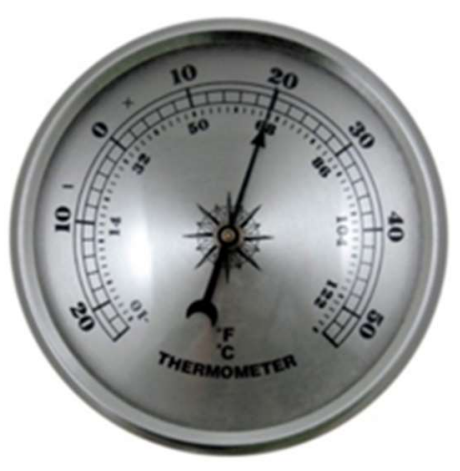

(b)

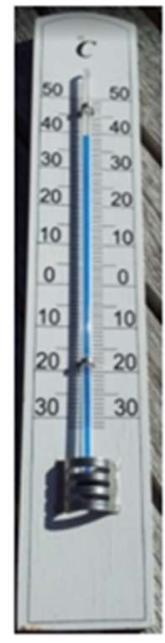

(c)

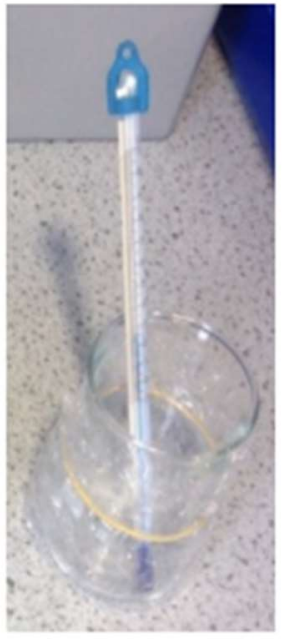

(d)

Figure 8. Different types of thermometers: (a) medical thermometer [72], (b) bimetallic thermometer [73], (c) outdoor thermometer [74], (d) laboratory thermometer [75].

Procedure: Assign the correct thermometer badges to the images.

Goal: To get familiar with basic types of thermometers.

Task 7. Outdoor temperature.

Tools: pictures showing certain weather conditions (Figure 9) and temperature cards (Figure 10). 


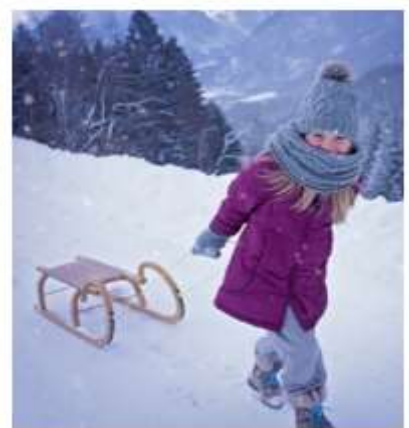

(a)

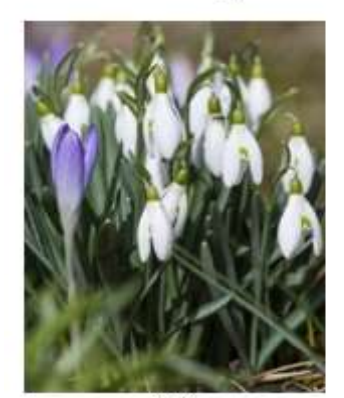

(d)

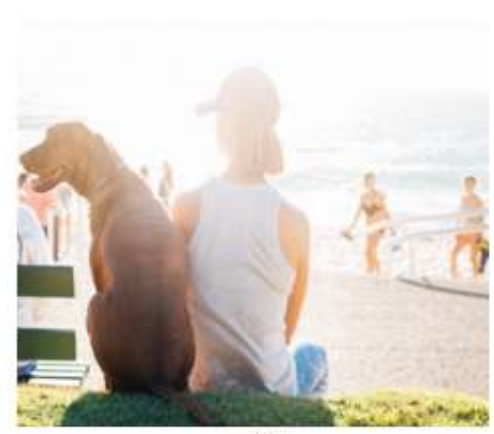

(b)

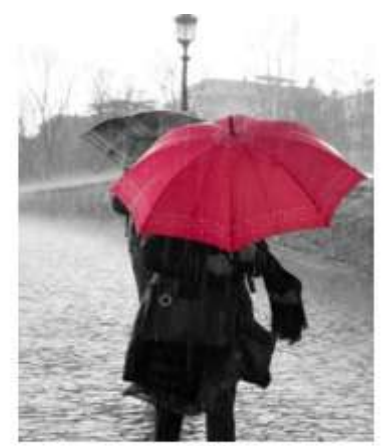

(c)

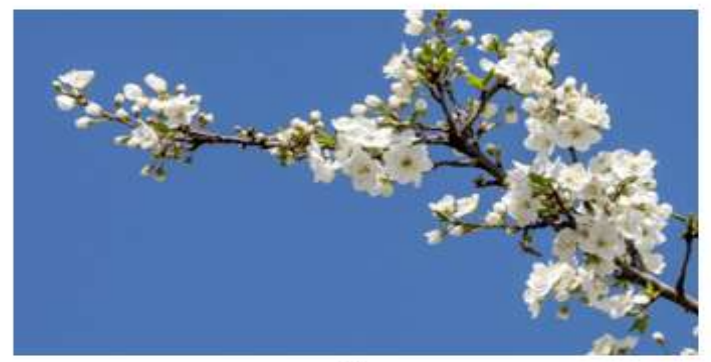

(e)

Figure 9. Different types of weather conditions: (a) sledging in winter [76], (b) sunbathing and swimming in summer [77], (c) rainy day in autumn [78], (d) snowdrops blooming in early spring [79], (e) flowering cherry tree in late spring [80].

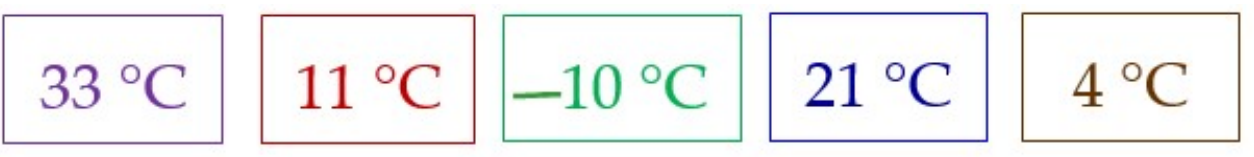

Figure 10. The cards with different temperature values.

Procedure: Based on your personal experience, assign the appropriate temperature to the following images (Figure 9). Each image shows certain weather conditions.

Goal: Based on personal experience, pupils are able to assign the appropriate temperature to images displaying different weather conditions.

Task 8. Weather pictograms.

Tools: an outdoor thermometer, schematic weather symbols (Figure 11). 

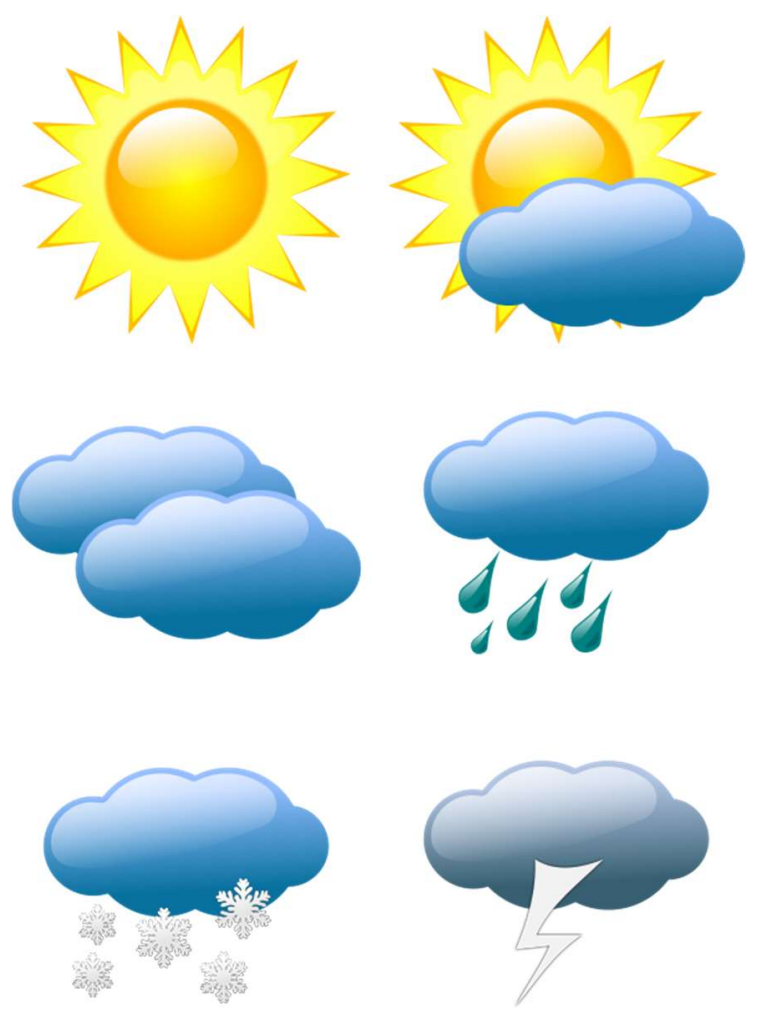

Figure 11. Schematic of weather symbols [81].

Procedure: By observing from the classroom window, estimate the outdoor temperature and determine the current weather conditions in the surroundings of the school. Using schematic symbols (Figure 11), write your findings down in a table prepared beforehand. Measure the actual temperature of the air by the outdoor thermometer and write down your findings in the table. Check whether the air temperature and the current weather you have estimated correspond to reality. Repeat the whole procedure once a day for one week. Discuss the weather changes that have occurred in the given period. When was the air temperature highest and when was lowest? When did you notice the largest difference in the air temperature? Is the air temperature related to current weather?

Goal: To be able to measure the air temperature at the school premises with an outdoor thermometer. To find out the current weather conditions and match it to the corresponding schematic symbol.

Task 9. Monitoring of the actual weather conditions in a place where you live via internet.

Tools: a computer or iPad, internet access.

Procedure: Open [82] and click on Weather-Current Conditions. Enter the name of your city/town/village into the search engine and find out the current air temperature in the place of your residence. Write down the acquired value in a table. Compare the air temperature of the place of your residence acquired from the Internet with the value measured directly with an outdoor thermometer in Task 8. Compare the values and explain the difference. Formulate the conclusion.

Click on [83] and answer the test questions. Check your answers.

Goal: To compare the air temperature from the place of pupils' residence, acquired in task 8 , with the air temperature found out on the Internet during the same period. To formulate conclusions.

Task 10: Monitoring of the actual temperature in a remote laboratory.

Tools: a computer or iPad, internet access.

Procedure: Open the real remote experiment of the meteorological station in Klatovy, Czech Republic [84]. For one week, record the daily temperature in the laboratory of a real 
remote experiment in Klatovy at hourly intervals. From the values obtained, find out when the temperature in the laboratory was maximal and when it was minimal. What was the magnitude of the difference between the highest and lowest temperature?

Goal: To monitor the actual temperature in a remote laboratory over the internet. To formulate conclusions.

Task 11. Based on the acquired information in the preceding tasks, prepare a project titled "Temperature Measurement".

Project objectives within the study curriculum: Pupils become responsible for a specific task and cooperate during data acquisition, acquire data, evaluate them, discuss them, cooperate, and suggest solutions. Pupils present the data in a chosen format and without losing their informative value. Pupils measure the air temperature with thermometer, both on-side and remote. They record the measurement values in a table.

Time duration: 1 week.

\subsubsection{Learning Activities of the Topic "Temperature Measurement" for CG}

The teaching in the CG took place in the traditional instructivist way, in which the teacher was the "owner of knowledge", and the pupil was the "expected recipient". The teacher verbally explained the curriculum covered. After the formal introduction, the teacher demonstrated several experimental tasks to the pupils. He was a demonstrator and pupils were engaged in the experiments under his/her guidance.

Task 1. Recognition of water temperature by touch

Experimental tools: 3 water containers of different temperatures. The containers were arranged in the following order: warm tap water $\left(40^{\circ} \mathrm{C}\right)$ on the left, lukewarm water $\left(20^{\circ} \mathrm{C}\right)$ in the middle, water with ice cubes $\left(0^{\circ} \mathrm{C}\right)$ on the right.

Procedure: Pupils go to the teacher one by one and immerse one hand in a container of warm water, lukewarm water, and ice-cold water. Each pupil writes his observations in a notebook. Subsequently, they discuss the results they reached in carrying out the experiment. At the end, the teacher formulates a conclusion.

Goal: To find out if a person can use touch to recognize different water temperatures.

Task 2. Recognition of thermometers.

Tools: Pictures of different thermometers from Smart Notebook Gallery [63], interactive whiteboard.

Procedure: The teacher selects pictures of different types of thermometers from the Smart Notebook Gallery and places them on the interactive whiteboard. Pupils walk one by one to the blackboard and write the appropriate name under each picture of the thermometer. The teacher checks the correctness of their solution. Finally, the teacher explains to pupils the difference between different types of thermometers.

Goal: To identify different thermometers.

Task 3. Construction of a simple thermometer.

Tools: a test tube, a narrow glass tube, water, ink, food coloring, a cork with an opening for the tube, an electric kettle, two glass containers (e.g., beakers).

Procedure: The teacher constructs a simple thermometer using a glass bottle, water, a straw and plasticine. The teacher explains to the pupils that if this thermometer is immersed in hot water, the ink in the straw will rise. If it is immersed it in cold water, the ink in the straw will drop. Finally, the teacher explains to the pupils that all liquid thermometers work on the same principle.

Goal: To explain the volume expansion of liquids depending on their temperature.

Task 4. Temperature measurement using laboratory thermometer.

Tools: cold water, ice cubes, electric kettle, beakers, liquid-in-glass laboratory thermometer.

Procedure: The teacher pours some tapped cold water into the beaker and places ice cubes in it. The teacher measures the iced water temperature with a laboratory thermometer 
and records the value on the whiteboard. Teacher boils water in the kettle. He/she pours the hot water into an empty beaker, measures its temperature with a thermometer and writes the value on the board. Finally, the teacher explains to the pupils that the cold water in which the ice cubes float has a temperature of $0^{\circ} \mathrm{C}$. The boiling water (at normal atmospheric pressure) has a temperature of $100{ }^{\circ} \mathrm{C}$.

Goal: To demonstrate the water temperature measurement with a general laboratory thermometer. To find out the actual water temperature.

Task 5. Body temperature measurement with medical thermometer.

Tools: medical thermometer, chalkboard, or Smart Board (interactive whiteboard).

Procedure: The teacher demonstrates a body temperature measurement. Each pupil measures his own body temperature with a medical thermometer and writes the measured value on a board. The teacher checks the accuracy of the measurement. From the measured values, pupils judge which of them has the highest and which the lowest body temperature. The teacher explains to the pupils what the elevated body temperature means. He/she also explains why the body temperature cannot be measured with meteorological or laboratory thermometer.

Goal: To be able to measure body temperature with a medical thermometer.

Task 6. Measurement of air temperature in classroom.

Tools: demonstration thermometer with an interchangeable scale (Figure 12), indoor thermometer.

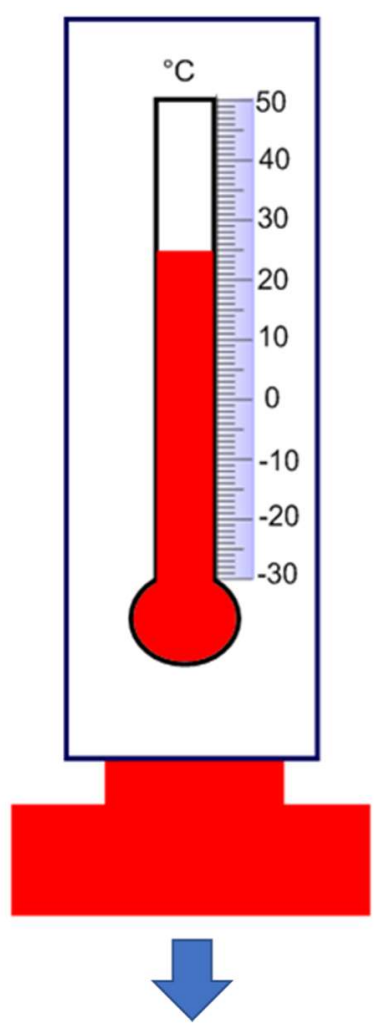

Figure 12. Demonstration thermometer with an interchangeable scale.

Procedure: The teacher controls the pupils' ability to identify the temperature measured on a demonstration thermometer. Pupils should correctly read the temperature, which is shown on the demonstration thermometer. Teacher also demonstrates the air temperature measurement in the classroom with a room thermometer.

Goals: To know that the room temperature is measured with an indoor thermometer. To be able to measure the air temperature in the classroom with a room thermometer.

Task 7. Outdoor temperature measurement at school premises. 
Tools: outdoor thermometer, Smart Board interactive whiteboard, Smart Notebook Gallery.

Procedure: The teacher walks the pupils to the outdoor thermometer located at the school building. Pupils determine the air temperature at the school premises and write down their findings in a table prepared in advance. They also indicate the current weather conditions for the measured temperature by using weather pictograms listed in the Smart Notebook Gallery (Figure 11).

Goals: To know that the air temperature is measured with an outdoor thermometer. To be able to measure the air temperature at the school premises with an outdoor thermometer. To find out the current weather and assign it the appropriate schematic symbol from the Smart Notebook Gallery.

\subsection{Data Analysis}

Prior to carrying out the pedagogical experiment, we gave the pupils a non-standardized didactic entrance test (pre-test, Table A1 in Appendix A). By pre-test we studied the level of pupils' pre-entry knowledge. The pre-entry knowledge of the topic, if it was markedly different in the EG and CG, could influence the scores of the post-tests later. Since the number of test tasks was smaller than 20, we decided to use a weighted scoring [85]. The pre-test questions covered the Temperature Measurement topic described earlier. The pre-test had 15 questions, which were aimed at knowledge reproduction, but also required the participants to apply their personal experience gained in their everyday life by making decisions and looking for connections. The maximum achievable score in the pre-test was 45 points.

After the completion of the pedagogical experiment, we presented the EG and CG with a non-standardized didactic test (post-test, Table A2 in Appendix A). As the number of questions in the post-test was less than 20, we applied a weighted scoring method to evaluate the pupils' results [85]. The post-test questions covered the topic taught in the EG and CG. The post-test had 10 tasks, which aimed at knowledge reproduction, but also required the pupils to use their everyday life experience in finding connections and making decisions. The maximum achievable score was 30 points.

\section{Results of Research}

A graphical representation of the score distribution in the pre-test is given in Figure 13. The statistical evaluation of pupils' scores in the pre-tests is presented in Table 1. The results show the maximum and minimum score values, the sample count, the standard deviation, and the variance. The average pre-test score in the EG was lower compared to the CG. However, the difference was not significant. In the CG, the confidence level was 2.73, which means that with $95 \%$ certainty the distribution center lies within the interval $18.67 \pm 2.73$. The confidence level was 2.78 in the EG, which means that with $95 \%$ certainty the distribution center lies within the interval $17.63 \pm 2.78$. Based on the results, we can conclude that the distribution of pre-test score count in both CG and EG had a smaller kurtosis than the standardized normal distribution and was negatively skewed.

A graphical distribution of post-test scores is given in Figure 14. The statistical evaluation of pupils' scores in pre-tests is also presented in Table 2 . The average post-test score in the EG was higher compared to the CG. The distribution of post-test results in both the EG and the CG had a smaller kurtosis than the standardized normal distribution and was positively skewed. In the CG, the confidence level was 2.57 , meaning that with $95 \%$ confidence the center of the distribution lied within the interval $16.27 \pm 2.57$. In the EG, the confidence level was 2.67, which means that with $95 \%$ confidence the center of the distribution lied within the interval $20.17 \pm 2.67$. The average score achieved in the EG was thus higher by approximately $24 \%$ compared to the CG. 

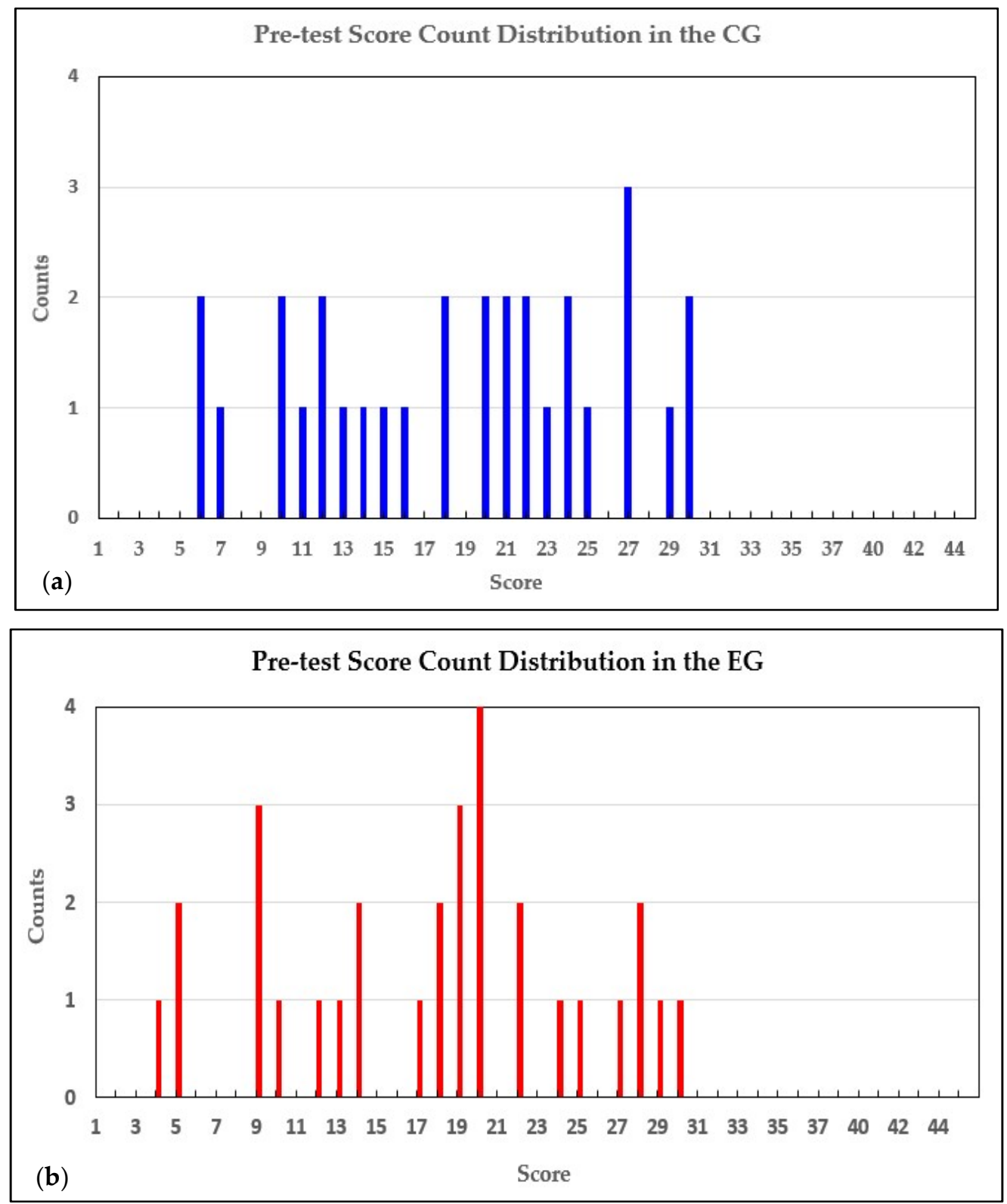

Figure 13. Graphical representation of the pre-test score count distribution in the CG (a) and EG (b). 

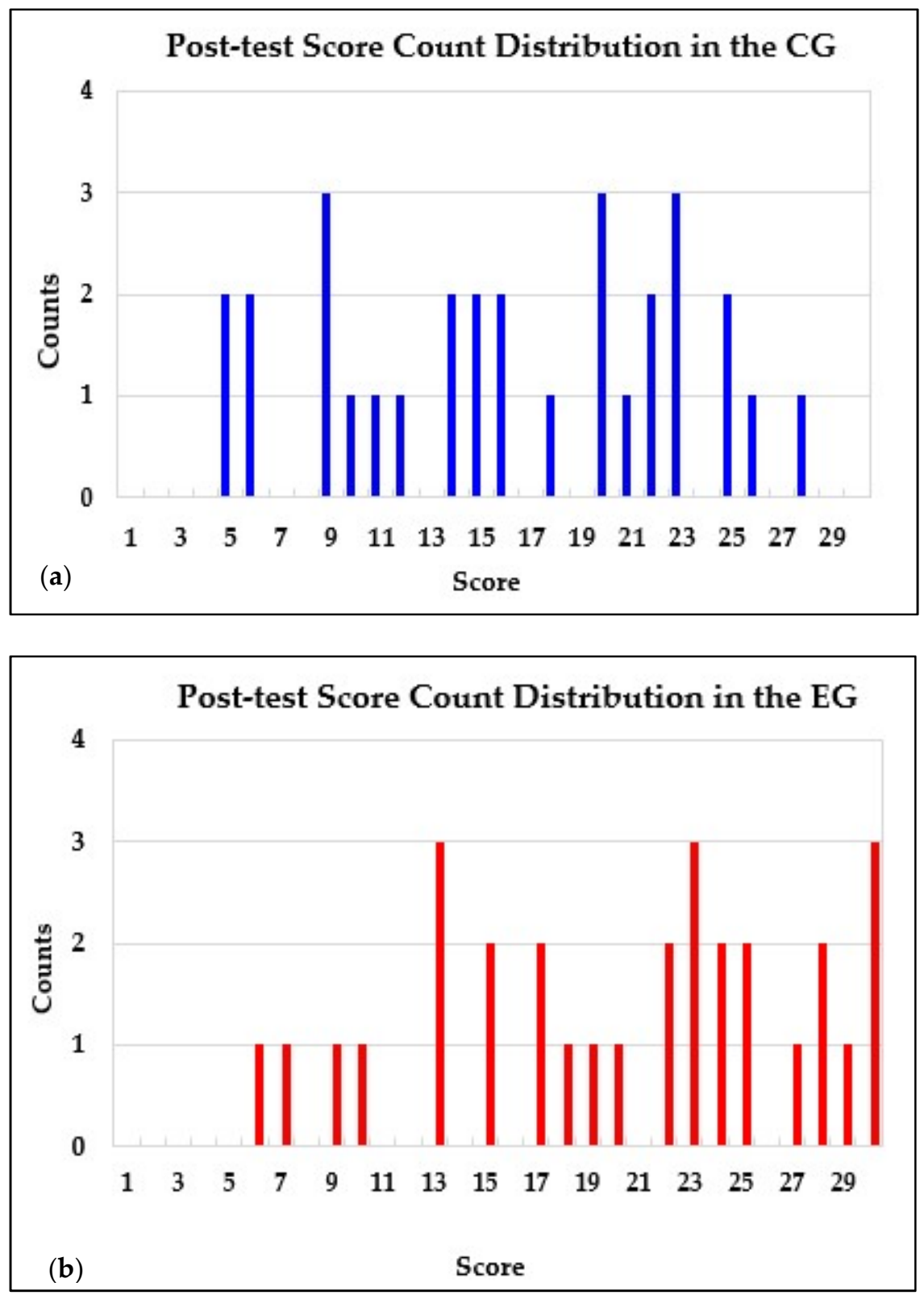

Figure 14. Graphical representation of the post-test scores in the CG (a) and EG (b). 
Table 1. Descriptive statistics-pre-test (EG, CG).

\begin{tabular}{ccc}
\hline Statistical Variables & Pre-Test & \\
\hline Mean & EG & CG \\
\hline Error of the Mean & 17.63 & 18.67 \\
Median & 1.36 & 1.34 \\
Modus & 19 & 20 \\
Stand. Deviation & 20 & 27 \\
Sample Variance & 7.46 & 7.32 \\
Kurtosis & 55.62 & 53.61 \\
Skewness & -0.82 & -1.08 \\
Difference max.-min. & -0.18 & -0.17 \\
Minimum & 26 & 24 \\
Maximum & 4 & 6 \\
Sum & 30 & 30 \\
Count & 529 & 560 \\
Highest score & 30 & 30 \\
Lowest score & 30 & 30 \\
Confidence Level (95.0\%) & 4 & 6 \\
\hline
\end{tabular}

Table 2. Descriptive statistics-post-test (EG, CG).

\begin{tabular}{ccc}
\hline Statistical Variables & Post-Test & \\
\hline & EG & CG \\
\hline Mean & 20.17 & 16.27 \\
Error of the Mean & 1.30 & 1.26 \\
Median & 22 & 16 \\
Modus & 23 & 20 \\
Stand. Deviation & 7.14 & 6.89 \\
Sample Variance & 51.04 & 47.44 \\
Kurtosis & -0.87 & -1.18 \\
Skewness & -0.38 & -0.14 \\
Difference max.-min. & 24 & 23 \\
Minimum & 6 & 5 \\
Maximum & 30 & 28 \\
Sum & 605 & 488 \\
Count & 30 & 30 \\
Highest score & 30 & 28 \\
Lowest score & 6 & 5 \\
Confidence Level (95.0\%) & 2.67 & 2.57 \\
\hline
\end{tabular}

\subsection{Fisher-Snedecor's F-Test for Pre-Test}

To find out whether the variance in both data sets was similar, we used a FisherSnedecor's F-test [85]. The test results are listed in Table 3. The variance was 55.62 in the EG and 51.58 in the CG. The chosen level of significance $(\alpha)$ was 0.05 . The test criterion $F$ was 1.08 (Table 3$)$. Based on the results, we can observe that the critical value $F_{0.05}(29 ; 28)$ is 1.88 and the calculated value of $F$ is 1.08 . The calculated $F$ value is lower than the critical value and, furthermore, $p>0.05$. Therefore, the null hypothesis must be adapted. As such, we can conclude that there were no statistically significant differences in the variance in both groups and the application of Student's $t$-test with equal variances is therefore justified. 
Table 3. Binomial F-test for Variance (EG, CG).

\begin{tabular}{|c|c|c|}
\hline \multirow[b]{2}{*}{ Statistical Variables } & \multicolumn{2}{|c|}{ Pre-Test } \\
\hline & EG & CG \\
\hline Mean & 17.63 & 18.31 \\
\hline Variance & 55.62 & 51.58 \\
\hline Observation & 30 & 29 \\
\hline Difference & 29 & 28 \\
\hline$F$ & 1.08 & \\
\hline$P(F \leq \mathrm{f})(1)$ & 0.42 & \\
\hline$F$ crit. (1) & 1.88 & \\
\hline
\end{tabular}

\subsection{Student's t-Test for Pre-Test}

We tested the null hypotheses in the Student's $t$-test using the $t$ criterion [85]. The results are presented in Table 4 . The chosen level of significance $(\alpha)$ was 0.05 . We compared the calculated value of $t$ with the critical value of the test criterion for the chosen level of significance (0.05) and the corresponding number of the degrees of freedom, in our case $f=58$. Based on the results given in Table 4 , we can conclude that the critical value of Student's $t$-test for 58 degrees of freedom at the chosen level of significance is $t_{0.05}(58)=2.00$. For the values shown in Table $4, t$ is equal to -0.54 . Since the calculated $t$ value is smaller than the critical value and, at the same time, $p>0.05$, we must adopt a null hypothesis. Therefore, we conclude that there were no statistically significant differences between the pre-test scores of the EG and CG.

Table 4. Binomial $t$-test with Homogeneity of Variance.

\begin{tabular}{|c|c|c|}
\hline \multirow[t]{2}{*}{ Statistical Variables } & \multicolumn{2}{|c|}{ Pre-Test } \\
\hline & EG & CG \\
\hline Mean & 17.63 & 18.67 \\
\hline Variance & 55.62 & 53.61 \\
\hline Observation & 30 & 30 \\
\hline Common Variance & 54.61 & \\
\hline Hyp. difference of Means & 0 & \\
\hline Difference & 58 & \\
\hline$t$ stat & -0.54 & \\
\hline$P(\mathrm{~T} \leq \mathrm{t})(1)$ & 0.30 & \\
\hline$t$ crit (1) & 1.67 & \\
\hline$P(\mathrm{~T} \leq \mathrm{t})(2)$ & 0.59 & \\
\hline$t$ crit (2) & 2.00 & \\
\hline
\end{tabular}

\subsection{Fisher-Snedecor's F-Test for Post-Test}

To find out whether the variance in both data sets was of the same size, we used the Fisher-Snedecor's F-test [85]. The results are displayed in Table 5. The chosen level of significance $(\alpha)$ was 0.05 . The variance of the results in the EG was 51.04. The variance of the results in the CG was 47.44. The test criterium $F=1,08$. Based on the results (Table 5), we can conclude that the critical value $F_{0.05}(29 ; 28)=1.86$ and the calculated value $F=1.08$. We found that the calculated $F$ value was lower than the critical value and $p>0.05$. As such, we adopted the null hypothesis, i.e., there were no statistically significant differences in the variance in both groups, and the application of Student's $t$-test with equal variances is therefore justified. 
Table 5. Binomial F-test for Variance (EG, CG).

\begin{tabular}{|c|c|c|}
\hline \multirow[b]{2}{*}{ Statistical Variables } & \multicolumn{2}{|c|}{ Post-Test } \\
\hline & EG & CG \\
\hline Mean & 20.17 & 16.27 \\
\hline Variance & 51.04 & 47.44 \\
\hline Observation & 30 & 30 \\
\hline Difference & 29 & 29 \\
\hline$F$ & 1.08 & \\
\hline$P(F \leq \mathrm{f})(1)$ & 0.42 & \\
\hline$F$ crit. (1) & 1.86 & \\
\hline
\end{tabular}

\subsection{Student's t-Test for Post-Test}

We tested the null hypotheses in the Student's $t$-test using the $t$ criteria. The results are presented in Table 6 . The chosen level of significance $(\alpha)$ was, again, 0.05 . We compared the calculated $t$ value with the critical value of the test criteria for the chosen level of significance (0.05) and the corresponding number of the degrees of freedom, in our case $f=58$. Based on the results, we can conclude that the critical value of Student's $t$-test for 58 degrees of freedom at the chosen level of significance was $t_{0.05}(58)=2.00$ For the values listed in Table 6, $t$ equals 2.15. As the calculated $t$ value is higher than the critical value and $p<0.05$, we must reject the null hypothesis. An alternative hypothesis is therefore valid, which means that between the post-test results of the EG and the CG, there was a statistically significant difference.

Table 6. Binomial $t$-test with Homogeneity of Variance.

\begin{tabular}{cccc}
\hline Statistical Variables & EG & Post-Test & CG \\
\hline Mean & 20.17 & 16.27 \\
Variance & 51.04 & 47.44 \\
Observation & 30 & 30 \\
Common Variance & 49.24 & \\
Hyp. difference of Means & 0 & \\
Difference & 58 & \\
$t$ stat & 2.15 & \\
$P(\mathrm{~T} \leq \mathrm{t})(1)$ & 0.02 & \\
$t$ crit $(1)$ & 1.67 & \\
$P(\mathrm{~T} \leq \mathrm{t})(2)$ & 0.036 & \\
$t$ crit $(2)$ & 2.00 & \\
\hline
\end{tabular}

\section{Discussion}

The Student two-phase $t$-test with dispersion equality proved that differences in the pre-test between the EG and the CG were not statistically relevant. Nevertheless, the differences in the final didactic test (post-test) between the EG and the CG were statistically relevant, i.e., there was a statistical dependency.

A comparison of pupils' achievements in the EG and the CG is presented in Figure 15. The difference between the groups in the amount of knowledge gained is remarkable. The average score in the CG was improved by $12 \%$ after the instructivist teaching. In the EG, the score has been improved by $25 \%$ (Figure 15). It shows the higher efficiency of inquiry-based learning compared to the instructivist approach. 


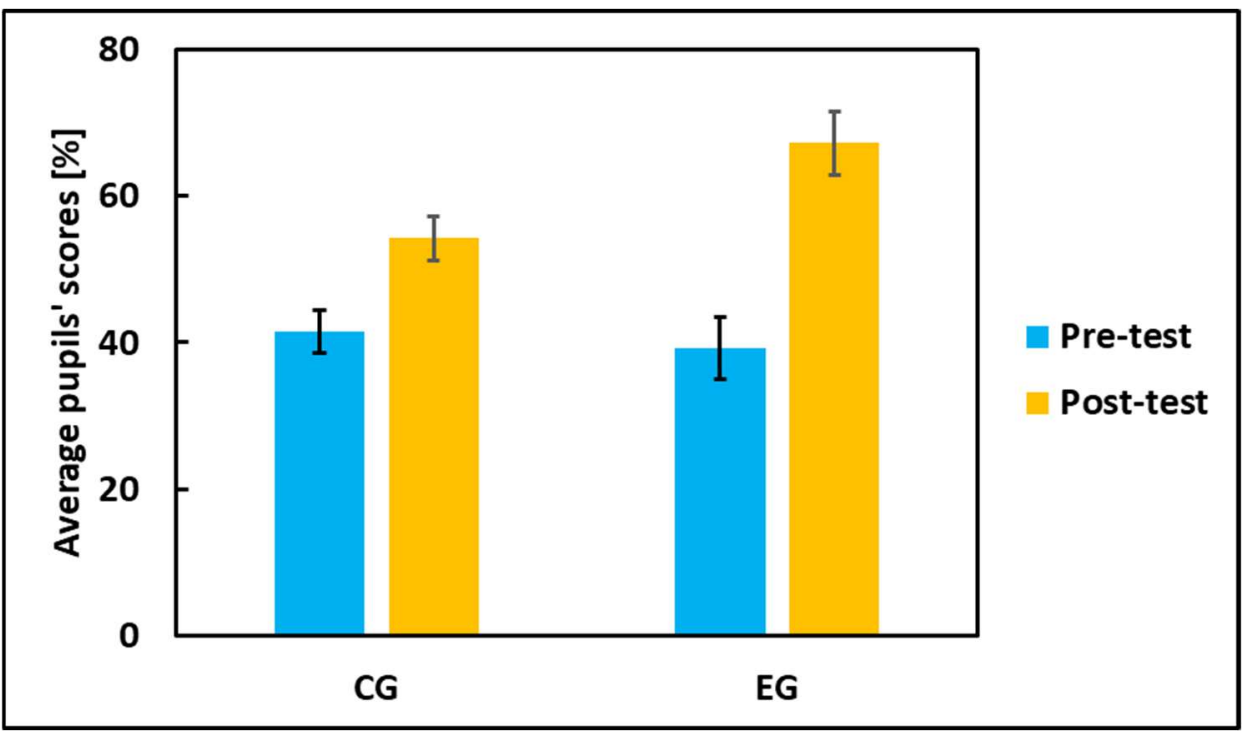

Figure 15. A comparison of average pupils' EG and CG scores in pre-test and post-test.

The analysis and evaluation of the pupils' results show the appropriateness of the introduction and wider implementation of project-based learning, using the IBL activities introduced into the educational process of the 3rd graders at Slovak primary school for the topic "Temperature Measurement". The pedagogical research verified the postulated hypothesis at the level of significance $\alpha=0.05$. The students' learning skills have been improved by $24 \%$ compared to the control group. As such, we can say that the projectbased teaching using the IBL activities for the topic "Temperature Measurement" was more efficient than the use of a traditional (instructivist) way of teaching.

Kostelníková and Ožvoldová [86] conducted a similar research study on a sample of 156 Slovak primary school pupils (69 boys and 87 girls aged 11 to 13 years). Their research evaluated the effectiveness of IBL with the combination of real remote experiments in the topic "Weather forecast-temperature measurement". The results of their study proved the effectiveness of the proposed methodology. The IBL, in combination with real remote experiments, resulted in better post-test scores of the experimental group compared to the control group. The pupils' skills in data recording and evaluation, i.e., how to plot a graph, how to read it, and how to calculate average values, were significantly improved. The noted improvement was related to the active involvement of the students in the construction of their knowledge. Moreover, the authors found predominantly positive attitudes of the pupils towards real remote experiments.

Our initial experience with IBL activities in Project-based Science education using the INTe-L strategy in science education with a focus on structured inquiry at the primary level was positively received. The pupils were able to solve the assigned tasks, and to develop, present, and defend their projects. Furthermore, our survey has also shown that pupils found the topic appealing. The pupils in the EG were asked to express their views on temperature measurement teaching at the end of the activity. The IBL activity for most of them was interesting (67\% respondents), and they said they found new information about temperature measurement (63\% respondents). We also asked pupils what they would change in the science teaching if they had the possibility. In response, $50 \%$ of pupils said they would like to conduct more experiments, $45 \%$ would not change anything, and 5\% would like to bring live animals to science class.

Consistent with the findings of our pedagogical research, previous studies also reported positive outcomes when PBL was used as a teaching model. For instance, the quantitative findings of study [87] realized in Kuala Lumpur, Malaysia, indicated that students exposed to the PBL curriculum outperformed the students who were taught using instructivism. The obtained interview responses further confirmed the positive 
outcomes of the quantitative findings. The findings of the previous studies focused on energy education $[51,84]$ suggest that project-based energy education significantly improves students' energy literacy. Furthermore, students taught using the PBL were found to take their learning more responsibly [87]. The PBL was used as an action-oriented method for developing pro-environmental behaviors of Turkey's pre-service teachers [88]. For instance, an improved content knowledge on ecology and scientific investigation skills was reported among high school students when they participated in an intertidal monitoring project building study [89]. Science, Technology, Mathematics, and Engineering PBL instruction of high school students resulted in improving the low-performing students' understanding of Mathematics [90].

Through a project-based activity, the research conducted by Lin, Kuen-Yi; Lu, ShaoChuan [91] explored how science education activities improve the energy literacy of third-year students in a senior high school in Taiwan. The PBL has been widely applied to stimulate learning motivation, cultivate implementation capability, and improve learning effectiveness [92]. The researchers have also indicated that employing proper educational technologies or learning strategies could further improve students' performance [93].

The process of inquiry is not a simple, straightforward process. Based on the curriculum and the nature of the investigation, the educator may emphasize different learning stages. Inquiry learning is a continuous activity as a single session rarely includes all inquiry stages [94]. Both scientists and teachers find it stimulating for pupils and beneficial for the development of their research skills and the construction of permanent scientific knowledge $[47,95]$. The scientific inquiry and project-based learning can foster the pupils ability to work, think, and act as scientists and communicate science as an important aspect of their soft skills.

\section{Conclusions}

Temperature and heat are challenging concepts for primary school children because of their abstractness. Previous studies have shown that young children had difficulties in making semantic links between different conceptions used by the scientific community [26,27]. Scientific terms such as heat and temperature were often misunderstood [28,29]. Regarding the concept of temperature, Paik, Cho, and Go observed that students had difficulties linking temperature with a measurement of a physical quantity [26]. Some pupils thought of temperature as a material's property. They also tended to summarize temperature the same way as heat [31].

It is now agreed that the learning of fundamental thermal concepts needs to address both semantic and semiotic challenges. An instructivist education of thermal concepts has traditionally used a textbook-based instruction. The text-based instruction, however, is limited in science teaching as learners are only involved as passive recipients of knowledge. In a previous study an image-to-writing approach in teaching of temperature and heat has been used [44]. Driven by the visualization practices of scientists, different modes of images (photos, sketches) were utilized to unveil the meanings of heat and temperature at the macroscopic level. The study has shown that the active demonstration has a potential to help pupils in gaining a conceptual understanding of thermal concepts. Nevertheless, knowing the rules of formal representation is not sufficient for developing deeper conceptual understanding of complex physical phenomena. The present paper shows that a more complex approach to teaching of thermal concepts should be utilized. It presents an application of the research-based method in the strategy of education. On a specific example of the topic "Temperature Measurement" in primary education, we have presented the possibility of using a "guided inquiry" in the implementation of individual experimental tasks. We have created a methodology for making simple scientific project assignments with the implementation of all components of the new integrated e-learning education strategy (real and real remote experiment, e-simulation, e-learning material). We have introduced a form of teamwork that allows teachers to harmonize the teaching 
requirements with individual learning approaches and helps to prepare pupils for planned work and independent knowledge acquisition and problem solving.

Teachers should stimulate their students' learning abilities by asking questions that activate their prior knowledge. The questions should be open-ended and focus the pupils' attention on scientific problem solving. Such questions promote the learners' text comprehension and improve science learning. Teachers should also invite their pupils to engage in discussions and make reasonable predictions. They should support students in applying the formal language system of science to make meaning of the physical phenomena around them. The integrated e-learning helped third graders to develop a deeper conceptual understanding of temperature and heat. It allowed them to prepare presentations to demonstrate their conceptual knowledge. The approach helped pupils to gain key competencies in Science (discussion and presentation of results). It has also increased the pupils' interest in Science and helped them to understand links between different subjects. To our best knowledge, the wider implementation of ICT in the inquiry-based learning of temperature and heat concepts for third graders has not been reported yet. Our approach is thus both novel and effective. Information and communication technologies can be effectively integrated into inquiry-based learning. An active inquiry-based learning involves an observation of natural phenomena. Modern ICT can be used to allow pupils to make their own observations. Real remote experiments accessible via internet can be used to observe natural phenomena over time. The e-learning can be integrated in primary school science education to provide an effective and clear instruction that supports young children's comprehension of causal mechanisms.

The goal of Science teaching is to provide a certain amount of knowledge. Nevertheless, it is also important to prepare pupils for an independent knowledge acquisition and problem solving. It is thus desirable to develop pupils' creative thinking, imagination, reasoning, and logical thinking, as well as to raise their interest in Science. The teaching helps them to verify a certain fact and substantiate it. Project-based teaching with IBL activities using the INTe-L strategy makes the teaching process more attractive. During the PBL process, the pupils have an opportunity to improve their soft skills, i.e., they learn to search for, sort, and process information that could be useful in their future life. It is therefore desirable to conduct further pedagogical studies aimed at verifying the effectiveness of the PBL with the support of IBL activities, including the INTe-L strategy, for other Science topics and other primary school subjects.

Author Contributions: Conceptualization, Ž.G. and M.P.; Data curation, Ž.G., P.P., M.D. and M.P.; Formal analysis, Ž.G. and M.P.; Investigation, Ž.G.; Methodology, Ž.G. and M.P.; Resources, Ž.G. and M.P.; Supervision, Ž.G. and M.P.; Writing—original draft, Ž.G.; Writing—review \& editing, Ž.G., M.D. and M.P. All authors have read and agreed to the published version of the manuscript.

Funding: This research was funded by Vedecká Grantová Agentúra MŠVVaŠ SR a SAV, grant number 1/0490/18. And Agentúra na Podporu Výskumu a Vývoja, grant number APVV-20-0124.

Institutional Review Board Statement: No personal information was collected from human participants, and data presented in this paper are not traceable to individual participants. All procedures involving humans were in accordance with the ethical standards of the institutional and/or national research committee.

Informed Consent Statement: Informed consent was obtained from all individual participants included in the study.

Data Availability Statement: Data are available from the authors.

Conflicts of Interest: The authors declare no conflict of interest. 


\section{Appendix A}

Table A1. Pre-test task definition.

\begin{tabular}{|c|c|}
\hline Question no. & Definition \\
\hline 1 & $\begin{array}{l}\text { Fill in the correct word in the next sentence. } \\
\text { A thermometer is used to measure } \ldots \ldots \ldots \ldots \ldots \ldots \ldots \ldots \ldots \ldots \ldots \\
\text { (a) heat (b) temperature }\end{array}$ \\
\hline 2 & $\begin{array}{l}\text { Write two types of thermometers you know. } \\
\ldots \ldots \ldots \ldots \ldots \ldots \ldots \ldots \ldots \ldots \ldots \ldots \\
\ldots \ldots \ldots \ldots \ldots \ldots \ldots \ldots \ldots\end{array}$ \\
\hline 3 & $\begin{array}{l}\text { Circle the correct answer. } \\
\text { A dimension of temperature is: } \\
\text { (a) kilogram } \\
\text { (b) degree Celsius } \\
\text { (c) meter } \\
\text { (d) liter }\end{array}$ \\
\hline 4 & Write down the value of a person's normal body temperature. ...... ${ }^{\circ} \mathrm{C}$. \\
\hline 5 & 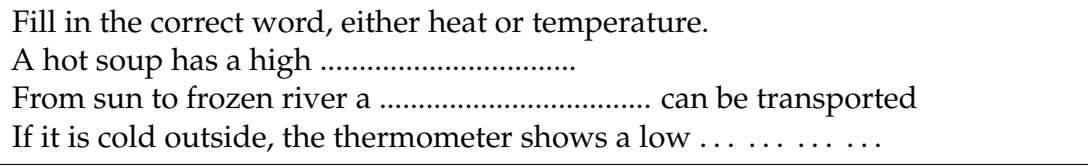 \\
\hline 6 & $\begin{array}{l}\text { Answer the following questions: } \\
\text { What happens to liquid water if we place it in a freezer? } \ldots \ldots \ldots \ldots \ldots \ldots \\
\text { What happens to an ice cube if it is placed in a cup of hot tea? } \ldots \ldots \ldots\end{array}$ \\
\hline 7 & $\begin{array}{l}\text { What happens to liquid water when it boils? Mark the correct answer. } \\
\text { (a) bubbles (b) changes color (c) nothing }\end{array}$ \\
\hline 8 & $\begin{array}{l}\text { Circle the correct answer: } \\
\text { When water boils it changes to (a) an ice (b) a steam }\end{array}$ \\
\hline 9 & 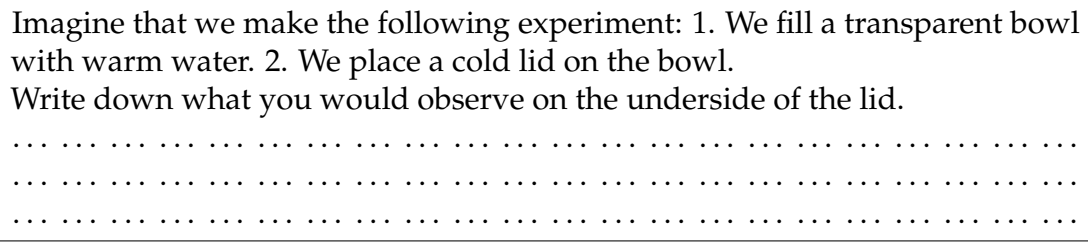 \\
\hline 10 & $\begin{array}{l}\text { Of the following values, the air has the lowest temperature when the } \\
\text { thermometer shows: (a) }-3{ }^{\circ} \mathrm{C} \text { (b) } 0{ }^{\circ} \mathrm{C} \text { (c) }-15^{\circ} \mathrm{C}\end{array}$ \\
\hline 11 & 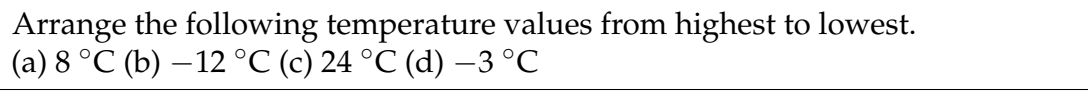 \\
\hline 12 & $\begin{array}{l}\text { Assign the correct characteristics of year seasons } \\
\text { A-fruits are harvested, leaves fall off } \\
\text { B-snow melts, trees are green } \\
\text { C-flowers blossom, air is very hot } \\
\text { D-water freezes, daylight is short } \\
\text { spring: } \ldots \ldots \ldots \ldots \\
\text { summer: } \ldots \\
\text { autumn: } \ldots \\
\text { winter: } \ldots\end{array}$ \\
\hline
\end{tabular}


Table A1. Cont.

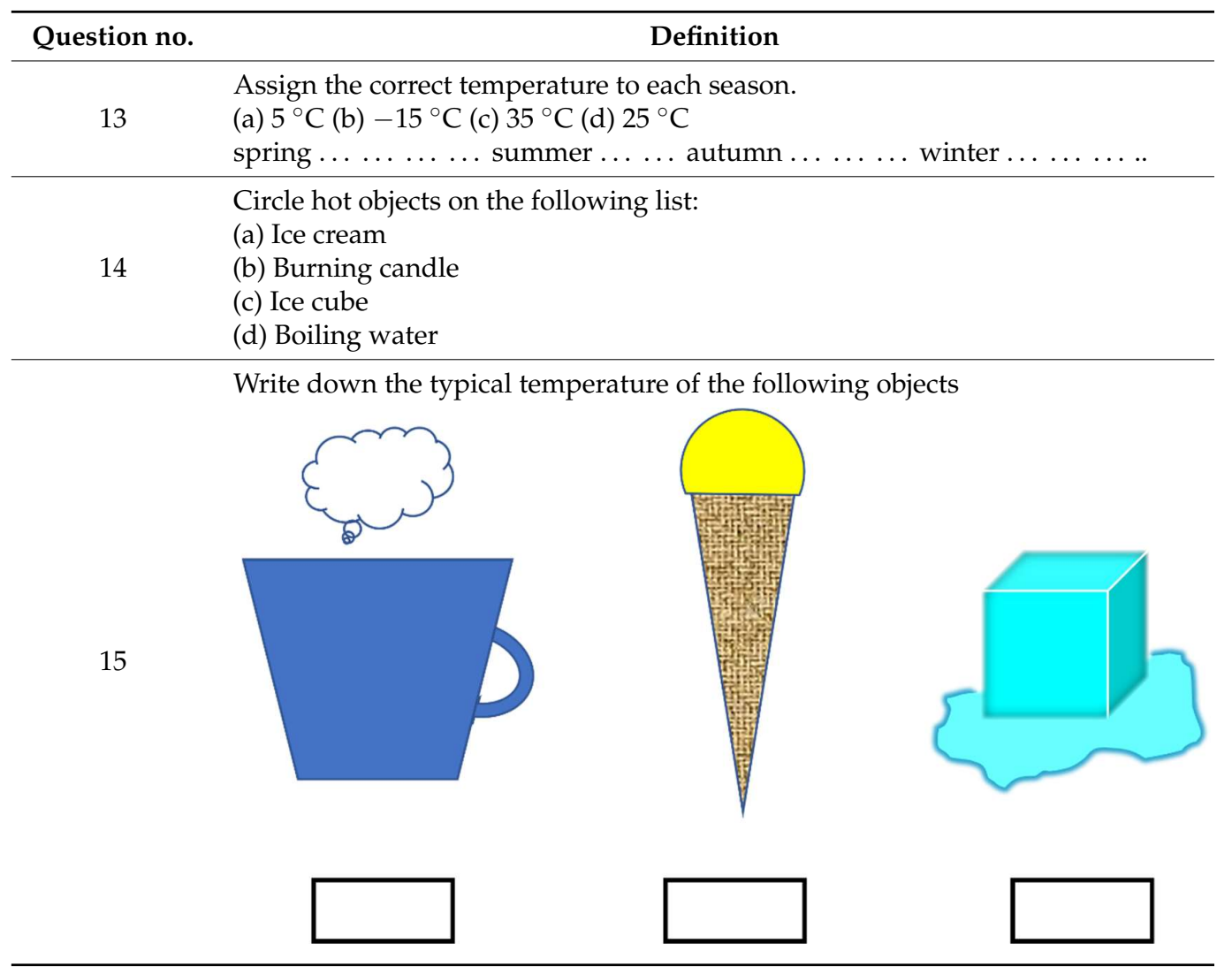

Table A2. Post-test task definition.

\begin{tabular}{|c|c|}
\hline Question no. & Definition \\
\hline \multirow{3}{*}{1} & Name 4 types of thermometers that you know. \\
\hline & 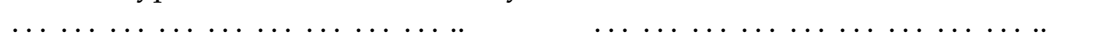 \\
\hline & 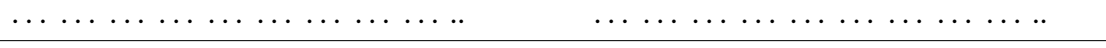 \\
\hline 2 & 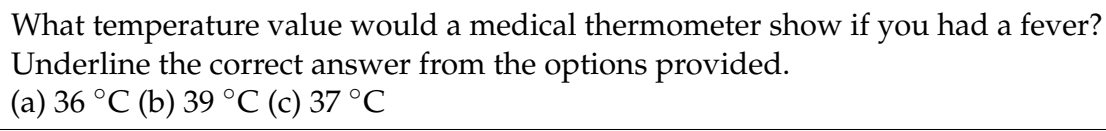 \\
\hline \multirow{3}{*}{3} & Indicate an elevated human body temperature on the following picture \\
\hline & 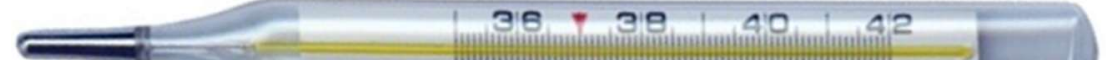 \\
\hline & $35 \quad 37 \quad 39 \quad 41 \cdot C$ \\
\hline 4 & $\begin{array}{l}\text { Fill in the correct answer: } \\
\text { (a) the boiling point of water is } \ldots \ldots \ldots \ldots \ldots \ldots{ }^{\circ} \mathrm{C} \text {. } \\
\text { (b) the melting point of ice is } \ldots \ldots \ldots \ldots \ldots \ldots \ldots{ }^{\circ} \mathrm{C} \text {. }\end{array}$ \\
\hline
\end{tabular}


Table A2. Cont.

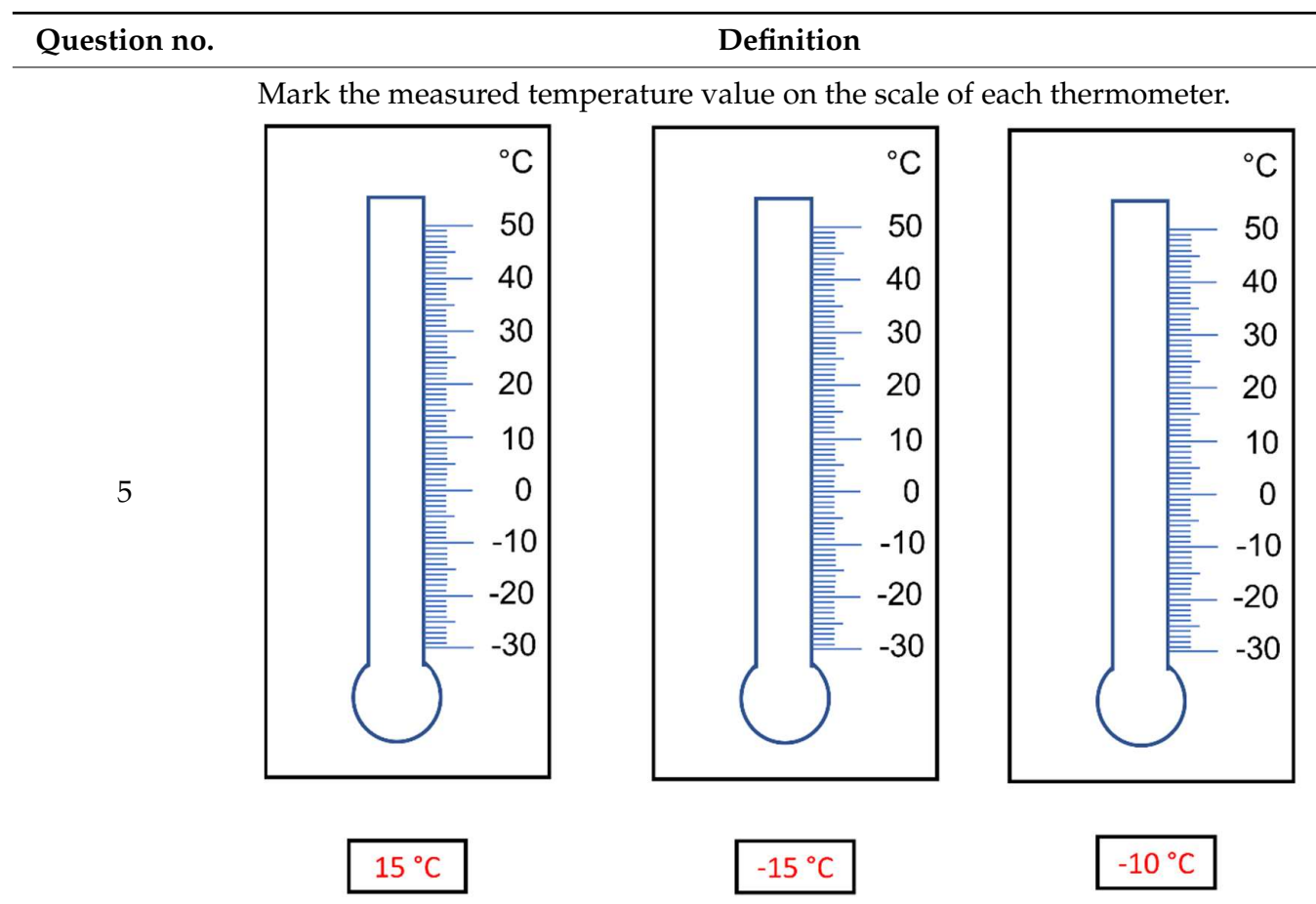

6 What can be a temperature of a snow flake? Mark all alternatives: (a) $-5{ }^{\circ} \mathrm{C}$ (b) $13{ }^{\circ} \mathrm{C}$ (c) $-3{ }^{\circ} \mathrm{C}$ (d) $20^{\circ} \mathrm{C}$

7 (a) $0{ }^{\circ} \mathrm{C}$, (b) $20^{\circ} \mathrm{C}$, (c) $100^{\circ} \mathrm{C}$, (d) smaller than $100{ }^{\circ} \mathrm{C}$, (e) higher than $0{ }^{\circ} \mathrm{C}$ Mark all possible answers.

Underline the correct answer:

8

We measure the body temperature body using:

(a) room thermometer, (b) medical thermometer,

(c) bimetallic thermometer, (d) any thermometer, that is not damaged.

Write down the temperature measured by each thermometer.
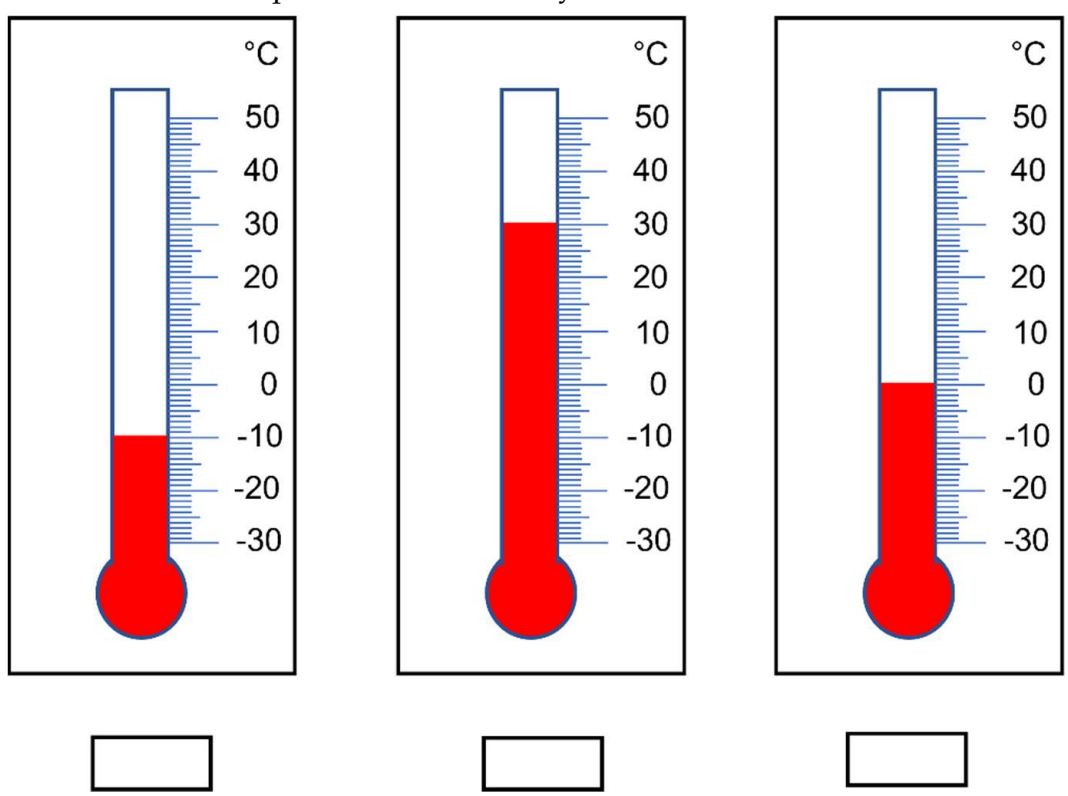


\section{References}

1. Pedaste, M.; Mitt, G.; Jürivete, T. What Is the Effect of Using Mobile Augmented Reality in K12 Inquiry-Based Learning? Educ. Sci. 2020, 10, 94. [CrossRef]

2. Pedaste, M.; Mäeots, M.; Siiman, L.A.; de Jong, T.; van Riesen, S.A.N.; Kamp, E.T.; Manoli, C.C.; Zacharia, Z.C.; Tsourlidaki, E. Phases of inquiry-based learning: Definitions and the inquiry cycle. Educ. Res. Rev. 2015, 14, 47-61. [CrossRef]

3. Keselman, A. Supporting inquiry learning by promoting normative understanding of multivariable causality. J. Res. Sci. Teach. 2003, 40, 898-921. [CrossRef]

4. Chu, S.K.W.; Reynolds, R.B.; Tavares, N.J.; Notari, M.; Lee, C.W.Y. 21st Century Skills Development Through Inquiry-based Learning; (eBook); Springer: Singapore, 2017; pp. 3-16. [CrossRef]

5. Karpudewan, M.; Zain, A.N.; Chandrasegaran, A.L. Overcoming Students'Misconceptions in Science Strategies and Perspectives from Malaysia; (eBook); Springer Nature Singapore Pte Ltd.: Singapore, 2017. [CrossRef]

6. Van Uum, M.S.J.; Verhoeff, R.P.; Peeters, M. Inquiry-based science education: Towards a pedagogical framework for primary school teachers. Int. J. Sci. Educ. 2016, 38, 450-469. [CrossRef]

7. Berg, C.A.R.; Bergendahl, V.C.B.; Lundberg, B.K.S.; Tibell, L.A.E. Benefiting from an open-ended experiment? A comparison of attitudes to, and outcomes of, an expository versus an open-inquiry version of the same experiment. Int. J. Sci. Educ. 2003, 25, 351-372. [CrossRef]

8. Vlaardingerbroek, B.; Taylor, N.; Bale, C.; Kennedy, J. Linking the experiential, affective and cognitive domains in biology education: A case study-microscopy. J. Biol. Educ. 2017, 51, 144-150. [CrossRef]

9. Bagalová, L.; Siváková, M. Activating Methods and Approaches in Natural Science Education (Application of Research Procedures in Science Teaching at Primary School)—Aktivizujúce metódy a prístupy v prírodovednom vzdelávaní (Uplatnenie bádatel'ských postupov vo vyučovaní prírodovedy na 1. stupni ZŠ). 2012. Available online: http:/ / www.statpedu.sk/files/ articles/dokumenty/vzdelavacie-aktivity/aktivizujuce-metody-v-prirodovede_fin.pdf (accessed on 2 July 2021). (In Slovak).

10. Wenning, C. Levels of Inquiry: Hierarchies of pedagogical practices and inquiry processes. J. Phys. Teach. Educ. Online 2005, 2, 3-11. Available online: http:/ / www.phy.ilstu.edu/pte/311content/inquiry/levels_of_inquiry.pdf (accessed on 2 July 2021).

11. The ESTABLISH (European Science and Technology in Action: Building Links with Industry, Schools and Home) Project. Available online: www.establish-fp7.eu (accessed on 2 July 2021).

12. Banchi, H.; Bell, R.L. Simple strategies for evaluating and scaffolding inquiry. Sci. Child. 2008, 45, 28-31.

13. Trundle, K.C. Teaching Science During the Early Childhood Years. Best Practices in Science Education. National Geographic. Available online: http://ngspscience.com/profdev/Monographs/SCL22-0429A_SCI_AM_Trundle_lores.pdf (accessed on 16 August 2021).

14. Kirschner, P.; Sweller, J.; Clark, R. Why minimal guidance during instruction does not work: An analysis of the failure of constructivist, discovery, problem-based, experimental, and inquiry-based teaching. Educ. Psychol. 2006, 40, 75-86. [CrossRef]

15. Zion, M.; Cohen, S.; Amir, R. The spectrum of dynamic inquiry teaching practices. Res. Sci. Educ. 2007, 37, 423-447. [CrossRef]

16. Hadzigeorgiou, Y. A study of the development of the concept of mechanical stability in preschool children. Res. Sci. Educ. 2002, 32, 373-391. [CrossRef]

17. Eshach, H.; Fried, M.N. Should science be taught in early childhood? J. Sci. Educ. Technol. 2005, 14, 315-336. [CrossRef]

18. Watters, J.J.; Diezmann, C.M.; Grieshaber, S.J.; Davis, J.M. Enhancing science education for young children: A contemporaryinitiative. Aust. J. Early Child. 2001, 26, 1-7. [CrossRef]

19. Ravanis, K.; Kaliampos, G.; Pantidos, P. Preschool Children Science Mental Representations: The Sound in Space. Educ. Sci. 2021, 11, 242. [CrossRef]

20. Piaget, J. Children's Conceptions of the World; Original Work Published 1928; Tomlinson, J.A., Translator; Littlefield Adams: Lanham, MD, USA, 1972.

21. Bell, B. Children's Science, Constructivism and Learning in Science; Deakin University: Geelong, Australia, 1993.

22. Duit, R.; Treagust, D.F. Students' conceptions and constructivist teaching approaches. In Improving Science Education; Fraser, B.J., Walberg, H.J., Eds.; The University of Chicago Press: Chicago, IL, USA, 1995; pp. 46-69.

23. Mbamalu, G.E. Teaching science to academically underprepared students. J. Sci. Educ. Technol. 2001, 10, 267-272. [CrossRef]

24. Atkins, P.; de Paula, J. Physical Chemistry, 8th ed.; W.H. Freeman and Company: New York, NY, USA, 2006; ISBN 0-7167-8759-8.

25. Tang, K.-S.; Tan, S.-C. Intertextuality and multimodal meanings in high school physics: Written and spoken language in computer-supported collaborative student discourse. Classr. Discourse 2017, 8, 19-35. [CrossRef]

26. Paik, S.H.; Cho, B.K.; Go, Y.M. Korean 4- to 11-year-old student conceptions of heat and temperature. J. Res. Sci. Teach. 2007, 44, 284-302. [CrossRef]

27. Jelinek, J.A. Children's Astronomy. Development of the Shape of the Earth Concept in Polish Children between 5 and 10 Years of Age. Educ. Sci. 2021, 11, 75. [CrossRef]

28. Alwan, A.A. Misconception of heat and temperature among physics students. Procedia Soc. Behav. Sci. 2011, 12, 600-614. [CrossRef]

29. Prince, M.; Vigeant, M.; Nottis, K. Development of the Heat and Energy Concept Inventory: Preliminary Results on the Prevalence and Persistence of Engineering Students' Misconceptions. J. Eng. Educ. 2012, 101, 412-438. [CrossRef] 
30. Sözbilir, M. A Review of Selected Literature on Students' Misconceptions of Heat and Temperature, Boğaziçi University. J. Educ. 2003, 20, 25-41.

31. Thomaz, M.F.; Malaquias, I.M.; Valente, M.C.; Antunes, M.J. An attempt to overcome alternative conceptions related to heat and temperature. Phys. Educ. 1995, 30, 19-26. [CrossRef]

32. Bar, V. Children's views about the water cycle. Sci. Educ. 1989, 73, 481-500. [CrossRef]

33. Kambouri-Danos, M.; Ravanis, K.; Jameau, A.; Boilevin, J.-M. The water state changes in 5-6 years old children's thinking: The construction of a precursor model. Early Child. Educ. J. 2019, 47, 475-488. [CrossRef]

34. Levins, L. Students' understanding of concepts related to evaporation. Res. Sci. Educ. 1992, 22, 263-272. [CrossRef]

35. Russell, T.; Harlen, W.; Watt, D. Children's ideas about evaporation. Int. J. Sci. Educ. 1989, 11, 566-576. [CrossRef]

36. Tytler, R. A comparison of year 1 and year 6 students' conceptions of evaporation and condensation: Dimensions of conceptual progression. Int. J. Sci. Educ. 2000, 22, 447-467. [CrossRef]

37. Bar, V.; Galili, I. Stages of children's views about evaporation. Int. J. Sci. Educ. 1994, 16, 157-174. [CrossRef]

38. Ravanis, K.; Papandreou, M.; Kampeza, M.; Vellopoulou, A. Teaching activities for the construction of a precursor model in 5-6 years old children's thinking: The case of thermal expansion and contraction of metals. Eur. Early Child. Educ. Res. J. 2013, 21, 514-526. [CrossRef]

39. Kaliampos, G.; Ravanis, K. Thermal conduction in metals: Mental representations in 5-6 years old children's thinking. J. Ilm. Pendidik. Fis. Al-BiRuNi 2019, 8, 1-9. [CrossRef]

40. Ravanis, K.; Bagakis, G. Science education in kindergarten: Sociocognitive perspective. Int. J. Early Years Educ. 1998, 6, 315-327. [CrossRef]

41. Sesto, V.; García-Rodeja, I. How Do Five- to Six-Year-Old Children Interpret a Burning Candle? Educ. Sci. 2021, 11, 213. [CrossRef]

42. Kampeza, M.; Vellopoulou, A.; Fragkiadaki, G.; Ravanis, K. The expansion thermometer in preschoolers' thinking. J. Balt. Sci. Educ. 2016, 15, 185-193.

43. Cruz-Guzmán, M.; García-Carmona, A.; Criado, A.M. Aprendiendo sobre los cambios de estado en educación infantil mediante secuencias de pregunta-predicción comprobación experimental [Learning about state changes in early childhood education through question-prediction sequences experimental testing]. Enseñanza De Las Cienc. 2017, 35, 175-193. [CrossRef]

44. Yeo, J.; Lim, E.; Tan, K.C.H.D.; Ong, Y.S. The Efficacy of an Image-to-Writing Approach to Learning Abstract Scientific Concepts: Temperature and Heat. Int. J. Sci. Math. Educ. 2021, 19, 21-44. [CrossRef]

45. Spencer, T.S.; Walker, T.M. Creating a Love for Science for Elementary Students through Inquiry-based Learning. J. Va. Sci. Educ. 2011, 4, 18-21.

46. Prince, M.; Vigeant, M.; Nottis, K. Using Inquiry-Based Activities to Repair Student Misconceptions Related to Heat, Energy and Temperature. Front. Educ. Conf. Proc. 2012, 1, 1-5. [CrossRef]

47. Alake-Tuenter, E.; Biemans, H.J.; Tobi, H.; Wals, A.E.; Oosterheert, I.; Mulder, M. Inquiry-Based Science Education Competencies of Primary School Teachers: A literature study and critical review of the American National Science Education Standards. Int. J. Sci. Educ. 2012, 34, 2609-2640. [CrossRef]

48. Suduca, A.-M.; Bizoia, M.; Gorghiu, G. Inquiry Based Science Learning in Primary Education. Procedia—Soc. Behav. Sci. 2015, 205, 474-479. [CrossRef]

49. Yoon, H.-G.; Joung, Y.J.; Kim, M. The challenges of science inquiry teaching for preservice teachers in elementary classrooms: Difficulties on and under the scene. Res. Sci. Educ. 2012, 42, 589-608. [CrossRef]

50. Condliffe, B.; Quint, J.; Visher, M.G.; Bangser, M.R.; Drohojowska, S.; Saco, L.; Nelson, E. Project-Based Learning A Literature Review; Working Paper; MDRC®: New York, NY, USA, 2017.

51. Gerhátová, Ž.; Perichta, P.; Palcut, M. Project-Based Teaching of the Topic "Energy Sources" in Physics via Integrated e-LearningPedagogical Research in the 9th Grade at Two Primary Schools in Slovakia. Education Sci. 2020, 10, 371. [CrossRef]

52. Schauer, F.; Ožvoldová, M.; Lustig, F. Integrated e-Learning-New Strategy of Cognition of Real World in Teaching Physics. Available online: https:/ /www.researchgate.net/profile/Franz-Schauer/publication/268257327_INTEGRATED_e-LEARNING_ -NEW_STRATEGY_OF_THE_COGNITION_OF_REAL_WORLD_IN_TEACHING_PHYSICS/links/55db16fe08aec156b9aed0 9c/INTEGRATED-e-LEARNING-NEW-STRATEGY-OF-THE-COGNITION-OF-REAL-WORLD-IN-TEACHING-PHYSICS. pdf (accessed on 4 November 2020).

53. Tkáč, L.; Schauer, F. Remote experiments for Integrated e-Learning in Electricity and Magnetism course. In Proceedings of the Conference REV 2011, Brasov, Romania, 28 June-1 July 2011; Kassel University Press: Brasov, Romania, 2011; pp. 262-269.

54. Literature Review: Conducting E Writing; University of West Florida: Pensacola, FL, USA, 2021; Available online: https: / /libguides.uwf.edu/c.php?g=215199\&p=1420520,\%20http:/ / ddeku.edu.in/Files / 2cfa4584-5afe-43ce-aa4b-ad936cc9d3be / Custom/Methods\%20of\%20educational\%20research.pdf (accessed on 30 August 2021).

55. Showkat, R.W. Methods of Educational Research. Available online: http://ddeku.edu.in/Files/2cfa4584-5afe-43ce-aa4b-ad936 cc9d3be/Custom/Methods\%20of\%20educational\%20research.pdf (accessed on 30 August 2021).

56. Koul, L.; Kumar, H.; Chawla, D.; Sondhi, N. Methodology of Educational Research. Available online: https:/ /www.tripurauniv. ac.in/Content/pdf/StudyMaterialsDetail/MA\%20Education\%202nd\%20Semester/EDCN-801C-Methodology\%20of\%20 Educational\%20Research.pdf (accessed on 30 August 2021).

57. Lodico, M.G.; Dean, T.; Spaulding, D.T.; Voegtle, K.H. Methods in Educational Research, From Theory to Practice; Jossey-Bass: San Francisco, CA, USA, 2006. 
58. Cohen, L.; Manion, L.; Morrison, K. Research Methods in Education, 6th ed.; Taylor \& Francis Group: Boca Raton, FL, USA, 2007.

59. Hrmo, R.; Kundrátová, M.; Tináková, K.; Vašková, L'. Didaktika Technických Predmetov/Didactics of Technical Subjects/; Slovak University of Technology: Bratislava, Slovakia, 2005; ISBN 80-227-2191-3. (In Slovak)

60. Žoldošová, K. Prírodoveda—štátny vzdelávací program (príloha); Science-State Educational Program (Supplement); The International Standard Classification of Education-ISCED 1; Štátny pedagogický ústav./State Pedagogical Institute: Bratislava, Slovakia, 2011; Available online: https://cloud7z.edupage.org/cloud/prirodoveda_isced1.pdf?z\%3AOtsxtITQBwrv4A6XhsLldJb9r\% 2FKLF2rZbZvie\%2BSjkD6nr7rW2cD2lnVppmurjOVw (accessed on 2 July 2021). (In Slovak)

61. Acher, A.; Arca, M.; Samnarti, N. Modeling as a teaching learning process for understanding materials: A case study in primary education. Sci. Educ. 2007, 91, 398-418. [CrossRef]

62. Kuhn, D.; Pease, M.A. What Needs to Develop in the Development of Inquiry Skills? Cogn. Instr. 2008, 26, 512-559. [CrossRef]

63. SMART Notebook18 Gallery—SMART Software; Smart Technologies: Calgary, AB, Canada, 2021; Available online: http://smarttech $\mathrm{com} / \mathrm{kb} / 171185$ (accessed on 2 July 2021).

64. Feverish woman-Picture. Available online: https://openclipart.org/detail/154741/feverish-woman (accessed on 2 July 2021).

65. Heated Milk_Picture. Available online: https://pxhere.com/sk/photo/1641470 (accessed on 2 July 2021).

66. Iron-Picture. Available online: https://pxhere.com/sk/photo/1158828 (accessed on 2 July 2021).

67. Ice Cream-Picture. Available online: https:/ / pxhere.com/sk/photo/698851 (accessed on 2 July 2021).

68. Hot Soup_Picture. Available online: https://pxhere.com/sk/photo/1641287 (accessed on 2 July 2021).

69. Orange Juice-Picture. Available online: https://pxhere.com/sk/photo/1600418 (accessed on 2 July 2021).

70. Iced water in a glass-Picture. Available online: https:/ / openclipart.org/detail/23869/glass (accessed on 2 July 2021).

71. The Interactive Simulation Entitled "Energy Forms and Changes". Available online: http://phet.colorado.edu/en/simulation/ energy-forms-and-changes (accessed on 2 July 2021).

72. Medical Thermometer-Picture. Available online: https://pxhere.com/sk/photo/1159519 (accessed on 2 July 2021).

73. Bimetallic Thermometer-Picture. Available online: https://pxhere.com/sk/photo/941464 (accessed on 2 July 2021).

74. Utility (Outdoor/Indoor) Thermometer-Picture. Available online: https://pxhere.com/sk/photo/893472 (accessed on 2 July 2021).

75. Laboratory Thermometer-Picture. Available online: https://pxhere.com/sk/photo/651822 (accessed on 2 July 2021).

76. Snowfall in Winter-Picture. Available online: https://pxhere.com/sk/photo/661555 (accessed on 2 July 2021).

77. Sunny in Hot Summer-Picture. Available online: https://pxhere.com/sk/photo/140294 (accessed on 2 July 2021).

78. Rainy in Autumn—Picture. Available online: https://pxhere.com/sk/photo/985062 (accessed on 2 July 2021).

79. Snowdrops and Crocuses in the Spring-Picture. Available online: https://pxhere.com/sk/photo/1134282 (accessed on 2 July 2021).

80. Blossoming Cherry in Spring_Picture. Available online: https://pxhere.com/sk/photo/1641901 (accessed on 2 July 2021).

81. Schematic of weather symbols —Picture. Available online: https://openclipart.org/detail/18414/weather-symbols (accessed on 2 July 2021).

82. Weather-Current Affairs. Available online: http:/ / pocasie.aktuality.sk/ (accessed on 2 July 2021).

83. Vuković, A.-M. Exploring Integers on a Temperature Scale. 2013. Available online: https://www.geogebra.org/m/gEvAbJ6C (accessed on 2 July 2021).

84. Meteorological station in Klatovy (Czech Republic)—The Real Remote Experiment. Available online: http://remote-lab.fyzika. net/experiment/12/experiment-12.php?lng=en (accessed on 2 July 2021).

85. Hahs-Vaughn, D.L.; Lomax, R.G. An Introduction to Statistical Concepts, 4th ed.; First Published 2020, eBook Published 21 February 2020; Routledge: New York, NY, USA, 2020. [CrossRef]

86. Kostelníková, M.; Ožvoldová, M. Inquiry in Physics Classes by means of Remote Experiments. Procedia-Soc. Behav. Sci. 2013, 89, 133-138. [CrossRef]

87. Karpudewan, M.; Ponniah, P.; Zain, A.N. Project-Based Learning: An Approach to Promote Energy Literacy Among Secondary School Students. Asia-Pac. Educ. Res. 2016, 25, 229-237. [CrossRef]

88. Kilinc, A.; Stanisstreet, M.; Boyes, E. Turkish students' ideas about global warming. Int. J. Environ. Sci. Educ. 2008, 3, 89-98.

89. Baumgartner, E.; Zabin, C.J. A case study of project-based instruction in the ninth grade: A semester-long study of intertidal biodiversity. Environ. Educ. Res. 2008, 14, 97-114. [CrossRef]

90. Han, S.; Capraro, R.; Capraro, M.M. How science, technology, engineering, and mathematics (STEM) project-based learning (PBL) affects high, middle, and low achievers differently: The impact of student factors on achievement. Int. J. Sci. Math. Educ. 2014, 13, 1089-1113. [CrossRef]

91. Lin, K.Y.; Lu, S.C. Effects of Project-based Activities in Developing High School Students' Energy Literacy. J. Balt. Sci. Educ. 2018, 17, 867-877. [CrossRef]

92. Chang, C.C.; Kuo, C.G.; Chang, Y.H. An Assessment Tool Predicts Learning Effectiveness for Project-Based Learning in Enhancing Education of Sustainability. Sustainability 2018, 10, 3595. [CrossRef]

93. Chang, S.-C.; Hwang, G.-J. Impacts of an augmented reality-based flipped learning guiding approach on students' scientific project performance and perceptions. Comput. Educ. 2018, 125, 226-239. [CrossRef] 
94. Worth, K.; Duque, M.; Saltiel, E. Designing and Implementing Inquiry-Based Science Units for Primary Education; Pollen: La main à la pâte 1, rue Maurice Arnoux 92120 Montrouge France 2009; Available online: https:/ /www.fondation-lamap.org/sites / default/ files/upload/media/Guide_Designing\%20and\%20implementing\%20IBSE_final_light.pdf (accessed on 2 July 2021).

95. Atmojo, I.R.W.; Sajidan; Sunarno, W.; Ashadi, A. Profile of Elementary School Pre-Service Teacher Based on High Order Thinking Skills (HOTS) on Natural Science Subject. Proceedings of the International Conference on Teacher Training and Education (ICTTE 2017), Faculty of Technics and Technologies of Yambol, Trakia University: Stara Zagora, Bulgaria; Volume 158, pp. 360-363. Available online: https: / / www.atlantis-press.com/proceedings/ictte-17/25885763 (accessed on 4 September 2021). [CrossRef] 